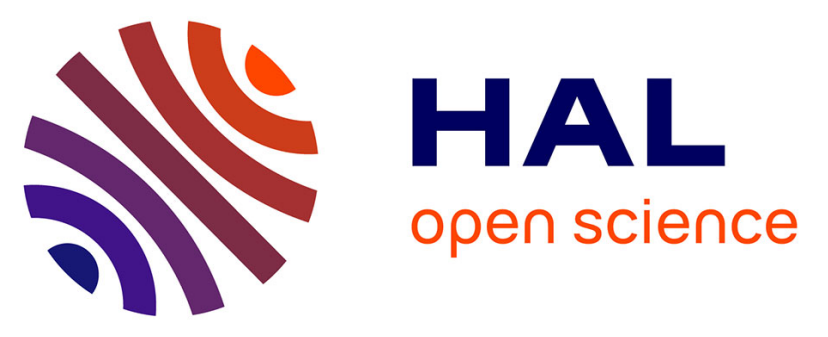

\title{
Ecological risk assessment of persistent organic pollutants (POPs) in surface sediments from aquaculture system
}

Nuning Vita Hidayati, Agung Dhamar Syakti, Vita Nuning, Laurence Asia, Imen Khabouchi, Franck Torre, Ita Widowati, Agus Sabdono, Pierre Doumenq, Agung Dhamar Syakti

\section{To cite this version:}

Nuning Vita Hidayati, Agung Dhamar Syakti, Vita Nuning, Laurence Asia, Imen Khabouchi, et al.. Ecological risk assessment of persistent organic pollutants (POPs) in surface sediments from aquaculture system. Chemosphere, 2021, 263, pp.128372. 10.1016/j.chemosphere.2020.128372 . hal03059637

\section{HAL Id: hal-03059637 https://hal.science/hal-03059637}

Submitted on 12 Dec 2020

HAL is a multi-disciplinary open access archive for the deposit and dissemination of scientific research documents, whether they are published or not. The documents may come from teaching and research institutions in France or abroad, or from public or private research centers.
L'archive ouverte pluridisciplinaire $\mathbf{H A L}$, est destinée au dépôt et à la diffusion de documents scientifiques de niveau recherche, publiés ou non, émanant des établissements d'enseignement et de recherche français ou étrangers, des laboratoires publics ou privés. 


\title{
Ecological risk assessment of persistent organic pollutants (POPs) in surface sediments from aquaculture system
}

\author{
Nuning Vita Hidayati a, b, c, Laurence Asia a, Imen Khabouchi a , Franck Torre ${ }^{\mathrm{d}}$, \\ Ita Widowati ${ }^{\text {c }}$, Agus Sabdono ${ }^{\text {c, Pierre Doumenq }}{ }^{\text {a }}$, Agung Dhamar Syakti e, f, * \\ ${ }^{a}$ Aix Marseille Univ, CNRS, LCE, Marseille, France \\ ${ }^{\mathrm{b}}$ Fisheries and Marine Science Faculty - Jenderal Soedirman University, Kampus Karangwangkal, Jl. Dr. Suparno, Purwokerto, 53123, Indonesia

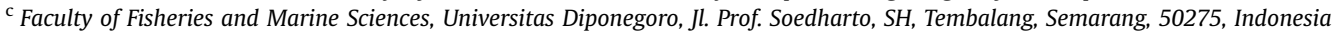 \\ ${ }^{\mathrm{d}}$ Aix Marseille Univ, CNRS, IMBE, IRD, Avignon Université, Marseille, France \\ e Environmental Science Department, Raja Ali Haji Maritime University, Jl. Politeknik Senggarang, Tanjungpinang, Riau Islands Province, 29100, Indonesia \\ ${ }^{\mathrm{f}}$ Center for Maritime Biosciences Studies, Institute for Sciences and Community Service, Jenderal Soedirman University, Kampus Karangwangkal, Jl. Dr. \\ Suparno, Purwokerto, 53123, Indonesia
}

\section{H I G H L I G H T S}

- The persistent organic pollutants were detected in the shrimp ponds.

- The occurrence patterns of the POPs in sediment were site dependent.

- The riverine system contributed to the higher concentrations of POPs.

- POPs may from historical inputs rather than a recent application.

- A risk assessment using several indices indicated potential adverse effects.

\section{Keywords:}

Persistent organic compounds

Pollution source

Northern coast of Java

Surface sediment

PCBs

OCPs
G R A P H I C A L A B S T R A C T

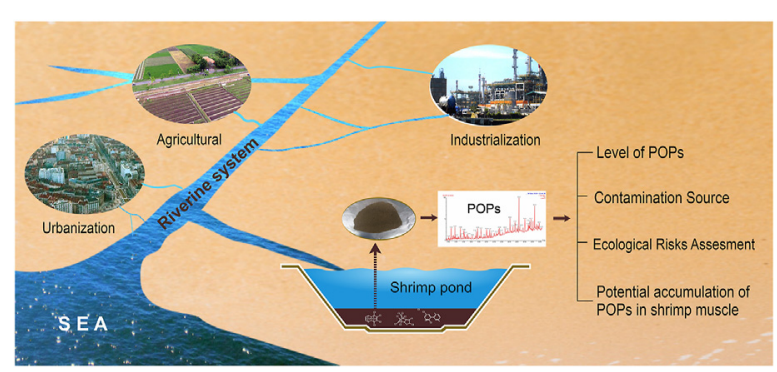

\section{A B S T R A C T}

Organochlorinated pesticides (OCPs) and Polychlorinated biphenyls (PCBs) in the surface sediments from shrimp ponds in four regions of the northern part of the Central Java coast (namely Brebes, Tegal, Pemalang, and Pekalongan) were investigated. The highest concentration of $\sum$ OCPs was found in Brebes Regency, ranging from $68.1 \pm 3.4$ to $168.1 \pm 9.8 \mu \mathrm{g} \mathrm{kg}^{-1} \mathrm{dw}$. As indicated by the DDT ratio and chlordane ratio, the value suggested that those compounds may mainly originate from historical inputs rather than a recent application. The concentrations of $\Sigma 7$ indicator PCBs were determined, with the concentration ranged from $1.2 \pm 0.7 \mu \mathrm{g} \mathrm{kg}{ }^{-1} \mathrm{dw}$ (Pekalongan) to $2.2 \pm 0.4 \mu \mathrm{g} \mathrm{kg}^{-1} \mathrm{dw}$ (Tegal). The most toxic PCB congener, PCB 118, was detected in all studied regions, with the highest proportion found in Tegal. Source analysis indicated that PCBs in the sediments mainly originated from Aroclor 1254 and Aroclor 1248. Compared to sediment quality guidelines (SQGs), some OCPs were found with concentrations which potentially posed an adverse effect. Our findings suggested that more attention should be paid to ensure sustainable shrimp culture facing such a risk of the OCPs and PCBs. 


\section{Introduction}

Indonesia is the world's third-largest rice producer, and Java is the main island for farming activities (USEPA, 2017; FAO, 2004). In Indonesian agricultural areas, including Java, pesticides have been massively used to kill and control organisms occurring on agricultural products and crops (Kartini et al., 2019), potentially resulted in a rapid increase in inputs of large numbers of pesticides into the environment (Glinski et al., 2018).

Furthermore, since around $13 \%$ of the Indonesian people live on Central Java with a very high population density, i.e. 1052 people/ $\mathrm{km}^{2}$, there is a dramatic impact of human activities on the environment through different anthropic activities. The growing population of Central Java (more than 34 million in 2018) have led to an increasing input of wastewater, mainly from industry, agriculture and households into aquatic system (BPS, 2019; Dsikowitzky et al., 2011). Furthermore, in line with the strong growth of the country, Indonesian coastal regions are developing very quickly due to commercial, agricultural, and industrial activities. Industrial and urban activities were previously identified as the possible sources of environmental contamination by PCBs. In addition, due to inadequate management, the contamination by anthropogenic pollutants on terrestrial and aquatic ecosystems might occur with a widespread and/or diffuse pollution (Sumon et al., 2018).

Previous authors stated that OCPs and PCBs, being mainly of anthropogenic origin, are transported to aquatic bodies by wastewater discharges (CCME and Environment, 1999), spray drift (Sumon et al., 2016), rain runoff, rivers and streams (Rabiet et al., 2010), and atmospheric deposition (Richards et al., 2016). These substances have become issues of most concern because of their bioaccumulative properties, persistency characteristic (Stockholm, 2011), and potential toxic effects to wildlife and human (GonzálezMille et al., 2010; Islam et al., 2018; Zhou et al., 2020).

In general, POPs are usually hydrophobic (i.e. "water-hating") and lipophilic (i.e. "fat-loving"). In aquatic systems, due to the latter properties, POPs bind strongly to solids, and more especially to organic matter (Ashraf, 2017), hence evading the aqueous compartment. Therefore, through sedimentation processes, sediments have become the primary reservoir of POPs (Ren et al., 2018). On the other hand, as the most important aquaculture commodities in Indonesia, white pacific shrimp (Litopenaeus vannamei) is considered as a benthic organism with a feeding behavior that easily accumulate chemicals from sediment (Martínez-Córdova and Peña-Messina, 2005; Varadharajan and Pushparajan, 2013). Some studies have shown that exposure to chlorinated pesticides caused protein decrease in exposed shrimp, increase in the larval respiratory rate, decrease of glycogen synthesis and nucleic acid content, suggesting drastic metabolic changes (Galindo Reyes et al., 1996). Moreover, OCPs can be retained in living organisms and indirectly threaten human health via ingestion because of their biomagnification capability through aquatic food chains to higher trophic (Ashraf, 2017; Ross and Birnbaum, 2003; Song et al., 2019).

Based on the Minister of Agriculture of the Republic of Indonesia Decree No. 434.1/Kpts/TP.270/7/2001; Minister of Agriculture of the Republic of Indonesia Decree No. 39/Permentan/SR.330/7/2015 and under Indonesia's ratification of the Stockholm Convention on POPs Convention in 2009, the use of these compounds are currently banned or severely restricted in Indonesia. As these chemicals persist in the environment and can remain for a very long time in sediments (Gavrilescu, 2005; Plimmer, 1992), their monitoring must be undertaken. It is important to provide the anthropogenic pollution status associated with their potential risk to the ecosystem, human health, and also the "remediation effects" of adequate management policy. In this study, as sediment is considered as the key matrix in the pollution monitoring programs and as a final sink for many particle-bound chemicals (Martinez et al., 2010), we monitored the presence of OCPs and PCBs in the sediment from 12 different aquaculture systems in the Northern part of Central Java Coast, Indonesia which is considered as the main shrimp producer.

\section{Materials and methods}

\subsection{Reagents and chemicals}

Pesticide 8081 standard mix containing 22 compounds, i.e., Aldrin, alpha-Hexachlorocyclohexane $(\alpha-\mathrm{BHC})$, gammaHexachlorocyclohexane $(\gamma$-BHC), beta-Hexachlorocyclohexane $(\beta$ BHC), delta-Hexachlorocyclohexane ( $\delta$-BHC), $\alpha$-Chlordane, $\gamma$ Chlordane, Dichlorodiphenyldichloroethane (4,4'-DDD), Dichlorodiphenyldichloroethylene (4,4'-DDE), Dichlorodiphenyltrichloroethane (4,4'-DDT), Decachlorobiphenyl, Dieldrin, $\alpha$-Endosulfan, $\beta$ Endosulfan, Endosulfan Sulfate, Endrin, Endrin Aldehyde, Endrin Ketone, Heptachlor, Heptachlor exo-epoxide, Methoxychlor, and 2,4,5,6-Tetrachloro- $m$-xylene was obtained from Sigma-Aldrich (St. Louis, MO, USA). While the individual pesticides (Chlorfenvinphos, Chlorpyriphos-ethyl, Alachlor, and Metolachlor) were obtained from LGC Standards GmbH D-46485 Wesel. PCB standards were purchased from Dr. Ehrenstorfer Laboratories (Augsburg, Germany). Basic alumina was purchased from VWR (Radnor, PA, USA), copper powder was purchased from Merck (Pessac, France), and Mega Bond Elut Florisil cartridges $(1 \mathrm{~g}, 6 \mathrm{~mL}$ ) were obtained from Agilent Technologies (USA). SupraSolv grade solvents, including dichloromethane (DCM), n-hexane (HEX) and acetone (ACE) were provided by Merck, Darmstadt, Germany. Hydrochloric acid (35\%), nitric acid (69\%) and phosphoric acid (85\%) of pure grades were provided by Fisher Scientific (Marseille, France). Analytical grades of potassium dichromate $\left(\mathrm{K}_{2} \mathrm{Cr}_{2} \mathrm{O}_{7}>99 \%\right)$ sulfuric acid $\left(\mathrm{H}_{2} \mathrm{SO}_{4}\right.$, 95-98\%), ferrous sulfate heptahydrate $\left(\mathrm{FeSO}_{4} \cdot 7 \mathrm{H}_{2} \mathrm{O}>99 \%\right)$ were bought from Merck, Darmstadt, Germany.

\subsection{Study area}

The sediment samples were collected from 12 stations corresponding to shrimp farms located in four regencies of the northern part of Central Java, namely Brebes, Tegal, Pemalang, and Pekalongan (see Fig. 1; Supplementary material, SM, Table S1). Besides, those regions were selected as they are among the highest shrimp producer regions in Central Java, and close to agricultural and/or urbanized areas.

\subsection{Sample collection}

In each pond, superficial sediment $(0-5 \mathrm{~cm})$ samples were collected in three points, thereby each sample was a composite sample, made up with three sub-samples. Then, the sediment was mixed in an aluminum tray, immediately placed in polyethylene bags and stored in a cool box with gel ice before being transferred to a laboratory. Upon arrival in the laboratory, sediment samples were subsequently freeze-dried over a period of a $72 \mathrm{~h}$, sieved through stainless steel sieves for a particle fraction of less than $2 \mathrm{~mm}$ size, and lightly ground in an agate mortar for homogenization. Then the samples were stored at $4{ }^{\circ} \mathrm{C}$ prior to analysis. 


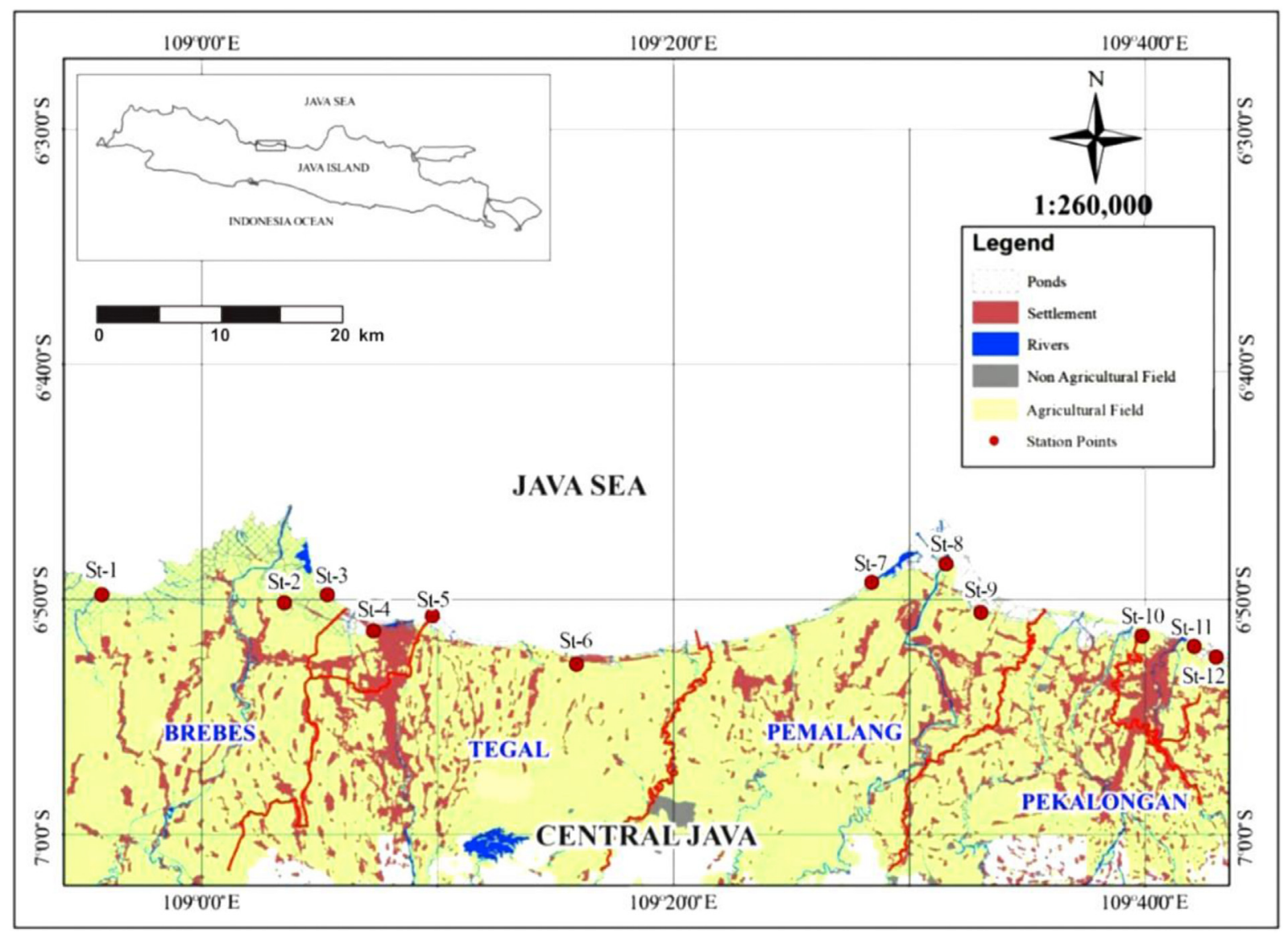

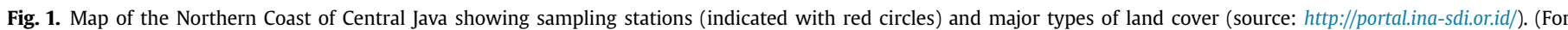
interpretation of the references to colour in this figure legend, the reader is referred to the Web version of this article.)

\subsection{Sample extraction}

Approximately $10 \mathrm{~g}$ sediment samples, $3 \mathrm{~g}$ of activated copper particles ( $>230$ mesh), and $4 \mathrm{~g}$ of activated alumina were mixed and then transferred to a $33 \mathrm{~mL}$ extraction cell of an accelerated solvent extraction system (ASE 350: Thermo Scientific, Waltham, MA). Surrogate deuterated standards $\left(4,4^{\prime}-\mathrm{DDE}-\mathrm{D}_{8}\right.$ and PCB $\left.156-\mathrm{D}_{3}\right)$ were added, then samples were equilibrated at room temperature for $1 \mathrm{~h}$ before extraction. The POPs in the sediment samples were then extracted with (HEX/ACE, 1:1 v/v) using a Thermo Scientific ${ }^{\mathrm{TM}}$ Dionex ${ }^{\mathrm{TM}}$-Accelerated Solvent Extractor ASE 350 with the following conditions: $100{ }^{\circ} \mathrm{C}, 1500 \mathrm{psi}, 5 \mathrm{~min}$ static time and $60 \%$ flush volume (Kanzari et al., 2012). The resulting extracts were then evaporated to about $2 \mathrm{~mL}$ with a rotary evaporator (Heidolph, Laborata 4000 efficient, Krackeler Scientific, Pessac, France), and the extract was further submitted to fractionation and clean-up.

The procedure used for purification and fractionation for OCPs and PCBs analyses was based on USEPA 3620C methods. Briefly, the concentrated extracts were purified and fractionated into fraction 1 and fraction 2 using MegaBond Elut Florisil Solid Phase Extraction (SPE) cartridges ( $1 \mathrm{~g}, 6 \mathrm{~mL})$. PCBs and some OCPs were eluted in "fraction 1" using $2.5 \mathrm{~mL}$ of $100 \%$ HEX (fraction 1), while the other OCPs was eluted in "fraction 2" using $5 \mathrm{~mL}$ of HEX/ACE (80/20 v/v). The eluent was collected in a $2 \mathrm{~mL}$ amber vial and then concentrated to about $1 \mathrm{~mL}$ under a gentle stream of nitrogen. After that, the concentrated eluent was transferred to a GC vial containing $8 \mu \mathrm{L}$ of PCB $116 \mathrm{D}_{5}$ as internal standards for GC-MS analysis.

\subsection{GC-MS analysis}

The sediment were analyzed for 22 individual organochlorine pesticides and transformation products: Aldrin, $\alpha$-Endosulfan, $4.4^{\prime}-$ DDD, 4.4'-DDE, 4,4'-DDT, Dieldrin, Endrin, $\alpha-\mathrm{HCH}, \beta-\mathrm{HCH}, \gamma-\mathrm{HCH}$, Heptaclor, Heptachlor Epoxide, $\delta-\mathrm{HCH}$, Alachlor, Metolachlor, Chlorpyriphos-ethyl, Chlorfenvinphos, $\gamma$-chlordane, $\alpha$-chlordane, Endrin Aldehyde, Endosulfan Sulfate, and Endrin Ketone. We also analyzed the seven indicator PCB congeners: 2,4,4Trichlorobiphenyl (PCB 28), 2,2,5,5-Tetrachlorobiphenyl (PCB52), 2,2,4,5,5-Pentachlorobiphenyl (PCB101), 2,2,4,4,5Pentachlorobiphenyl (PCB118), 2,2,4,4,5,5-Hexachlorobiphenyl (PCB153), 2,2,3,4,4,5-Hexachlorobiphenyl (PCB138), 2,2,3,4,4,5,5Pentachlorobiphenyl (PCB180). Identification and quantification of OCPs and PCBs were performed in both SIFI mode (full scan) and selected ions recording (SIR) mode data collection running simultaneously. Retention times and characteristic ions of studied compounds are displayed in Table S2. The gas chromatography (PerkinElmer AutoSystems XL, California, USA), equipped with a Restek Rxi-XLB (30 m $\times 0.25 \mathrm{~mm}$ i. d. $\times 0.25 \mu \mathrm{m}$ film thickness, Restek Corporation) capillary column, and coupled with a Clarus 600C mass spectrometer (MS) was used for determining the concentrations of the POPs in the sediment samples. The GC oven temperature was programed as follows: initial temperature $70{ }^{\circ} \mathrm{C}$ ( 2 min), then raised to $175^{\circ} \mathrm{C}\left(10^{\circ} \mathrm{C} \mathrm{min}{ }^{-1}\right)$ and held isothermally for $4 \mathrm{~min}$, then raised to $320{ }^{\circ} \mathrm{C}\left(5^{\circ} \mathrm{C} \mathrm{min}^{-1}\right)$ and finally held for $1 \mathrm{~min}$. The injector was set from $50{ }^{\circ} \mathrm{C}(0.1 \mathrm{~min}$ isothermal $)$ to $250{ }^{\circ} \mathrm{C}\left(200{ }^{\circ} \mathrm{C} \mathrm{min}^{-1}\right)$ held for $10 \mathrm{~min}$. MS was run in the electron 
ionization (EI) mode ( $70 \mathrm{eV}$ ) at a source temperature of $300^{\circ} \mathrm{C}$. The samples were injected in the splitless mode, and a high-purity helium was used as the carrier gas with a constant flow of $1 \mathrm{~mL} \mathrm{~min}^{-1}$.

\subsection{Sediment grain size and organic carbon determination}

All samples were analyzed both for grain size and organic matter. Sediment grain size was determined "manually" by wet sieving through a series of ISO 3310-1 stainless steel sieves (Retsch France): sand (between $0.250 \mathrm{~mm}$ and $2 \mathrm{~mm}$ ), fine sand (between $0.063 \mathrm{~mm}$ and $0.250 \mathrm{~mm}$ ), and mud or silt and clay $(<0.063 \mathrm{~mm})$. Each fraction was dried, weighed, and classified according to Folk's classification. Total Organic Carbon (TOC) content was determined based on the Walkley-Black chromic acid wet oxidation method. In brief, oxidizable matter in the sediment was oxidized by $1 \mathrm{~N}$ $\mathrm{K}_{2} \mathrm{Cr}_{2} \mathrm{O}_{7}$ solution. The reaction is helped by the heat generated when two volumes of $\mathrm{H}_{2} \mathrm{SO}_{4}$ are mixed with one volume of $\mathrm{K}_{2} \mathrm{Cr}_{2} \mathrm{O}_{7}$. The remaining $\mathrm{K}_{2} \mathrm{Cr}_{2} \mathrm{O}_{7}$ is titrated with $\mathrm{FeSO}_{4}$. The titer of the solution is inversely related to the amount of $\mathrm{C}$ present in the sediment sample (Wang et al., 2019; Zhao et al., 2016).

\subsection{Quality assurance/quality control ( $Q A / Q C)$}

All analytical procedures were performed under strict quality assurance and control procedures. In order to control any contamination during chemical analysis, laboratory blanks were included in every set of three samples and treated in the same manner as the samples. In all the blank samples, the values were lower than the detection value. A certified reference material (CRM) CNS391 "PAHs, PCBs and Pesticides on freshwater sediment" (Sigma-Aldrich, Molsheim, France) was used to evaluate the method performance. Each sample was processed in triplicate.

Calibration curves of individual target OCP and PCB exhibited a very good linear response $\left(r^{2}>0.999\right)$ for quantification by GC-MS. Detection limits (LODs) defined as 3 times baseline noise was comprised between $0.04 \mathrm{ng} \mathrm{g}^{-1}$ and $0.71 \mathrm{ng} \mathrm{g}^{-1}$ for OCPs and $0.02-0.13 \mathrm{ng} \mathrm{g}^{-1}$ for PCBs. Recovery rates of $82 \%-94 \%$ were obtained for target compounds. Concentrations of OCPs and PCBs were determined based on standard surrogate of 4,4-DDE $\mathrm{D}_{8}$ and PCB156 $\mathrm{D}_{3}\left(100 \mathrm{pg} \mu \mathrm{L}^{-1}\right)$. Internal standard solutions $\left(40 \mathrm{pg} \mu \mathrm{L}^{-1}\right)$ of PCB116- $\mathrm{D}_{5}$ were injected to samples before GC/MS analysis to calculate surrogate recoveries and target compounds. The results for OCPs and PCBs analysis are expressed in $\mu \mathrm{g} \mathrm{kg}^{-1}$ dry weight $(\mathrm{dw})$.

\subsection{Data analysis}

The statistical analyses were performed using $\mathrm{R}$ statistics package. We performed statistical analyses using nonparametric tests i.e. Kruskal-Wallis test to highlight differences in the concentration of the OCPs occurrences among regions. Characterization of PCBs homolog were performed with Principal Component Analysis (PCA). In addition to the statistical analyses, diagnostic ratios were used to distinguish the sources of emission and pollution input history, i.e. HCH ratio; cis-chlordane/trans-chlordane ratio; p, $\mathrm{p}^{\prime}-(\mathrm{DDE}+\mathrm{DDD}) / \mathrm{p}, \mathrm{p}^{\prime}$-DDT ratio; and $\sum$ DDTs/ $\sum$ PCBs.

The $\sum$ HCHs was defined as the sum of $\alpha-\mathrm{HCH}, \beta-\mathrm{HCH}, \gamma-\mathrm{HCH}$ $\mathrm{HCH}$ isomer composition, as previously described by (Tan et al., 2009) and (Qiu et al., 2019). High $\alpha-\mathrm{HCH} / \beta-\mathrm{HCH}$ ratios usually indicate current sources of technical $\mathrm{HCH}$, while low ratios suggest historical sources (Qiu et al., 2019). The values of $\alpha-\mathrm{HCH} / \gamma-\mathrm{HCH}$ in environmental samples can be used to monitor whether a source was technical $\mathrm{HCH}$ or lindane. The ratio of $\alpha-\mathrm{HCH}$ to $\gamma-\mathrm{HCH}$ concentrations between 3 and 7 (Mitra et al., 2019) or between 4 and 7 (Tang et al., 2020) indicated the possible source of technical $\mathrm{HCHs}$, while the ratio $<4$ indicates the use of lindane. Cischlordane/trans-chlordane ratio is evaluated based on (Alam et al., 2014). The value of cis-chlordane to trans-chlordane ratios $<0.79$ indicates the recent uses of commercial chlordane, while the value $>0.79$ suggests historical use of commercial chlordane. Then, DDT ratio was used to investigate the source of DDT, and calculated according to the previous works (Neves et al., 2018; Tran et al., 2019):

$$
\text { DDTs ratios }=\frac{p, p^{\prime}-\mathrm{DDT}}{p, p^{\prime}-\mathrm{DDE}+p, p^{\prime}-\mathrm{DDD}}
$$

Briefly, a DDTs ratio $<1$ indicates a past input while a DDTs ratio $>1$ indicates modern/recent input ( $<5$ years).

\section{Results and discussion}

\subsection{Organic carbon and sediment grain size}

In terms of OCPs distribution in sediments, factors such as sediment texture, organic carbon, land use and seasonal variation have been found to exert influence (Duodu et al., 2017). TOC concentration is considered as an important factor in relation to the distribution of organic contaminants (CCME and Environment, 1999). In the present study, we found a positive correlation between concentrations of OCPs and TOC $\left(R^{2}=0.77\right)$. A similar tendency was reported by (Huo et al., 2017) in Lake Chaohu sediments, China and (Lv et al., 2020) in 14 typical intertidal zones of China. The average of TOC in the studied sediments of the shrimp ponds $(1.9 \pm 1.8 \%)$ was in medium level, that is lower to those coastal waters around intensive shrimp ponds in Lampung province, Indonesia (ranged between 0.30 and $9.85 \%$, average $3.09 \%$ ) and much lower to those from the 5-year-old shrimp culture ponds in the Shanyutan wetland of Min River estuary, South-east China $(22.4 \pm 2.0 \%)$ (Gao et al., 2019); comparable to those Cua Hoi Estuary (average 1.72\%) and Han River Estuary (average 1.78\%) in coastal area of central Vietnam (Tham et al., 2019).

Site 3 (Brebes) presents the highest of TOC $(5.9 \pm 1.7 \%)$, while site 3 in Pekalongan is the site with the lowest TOC $(0.3 \pm 0.01 \%)$. A study by (Gao et al., 2019) shown that shrimp aquaculture significantly increased sediment TOC as a result of the decomposition of a large number of residual feeds and excrement. A similar result reported by (Gao et al., 2018) in their previous work in the 3-yearreclamation culture ponds in Coastal Zone of Southeastern China. In addition, Yang et al. (2017) found that $\mathrm{CH}_{4}$ emission fluxes in shrimp ponds were clearly high during the mid and later part of the aquaculture season and were directly proportional with TOC level $(16.2 \pm 0.6 \%)$.

Other factors also play an important role on the distribution and concentration of POPs in sediments, such as sediment grain size (Barhoumi et al., 2014). Our results demonstrated that there was a weak positive relationship between mud and OCPs level in the surface sediment samples $\left(\mathrm{R}^{2}=0.51\right)$. Similarly, we found a weak positive relationship between clay (mud and silt) and sediment organic carbon contents in shrimp ponds $\left(R^{2}=0.56\right)$, which is consistent with the previous results obtained by Bergamaschi et al. (1997), Flemming and Delafontaine (2000), and Lee et al. (2019). In general, sediment properties such as grain size and composition are known as important environmental factors to determine the distributions and fate of organic matters in the shallow water system (Serrano et al., 2016). For example, muddy sediment mainly composed of silt and clay retains more organic matter compared to coarse-grained sediments (e.g. sand), due to a greater adsorption 
capacity of fine-grained particles by earning a larger surface area (Burdige, 2007; Keil and Hedges, 1993).

\subsection{The occurrence and sources of organochlorine pesticides (OCPs)}

Concentrations of OCPs are presented in Table 1, showing that despite the ban of aldrin, dieldrin, heptachlore, cis-chlordane, endosulfan, DDT, and $\alpha-\mathrm{HCH}$ in Indonesia (based on the Decree of Indonesian Minister of Farming Letter No. 434.1/Kpts/TP.270/7/ 2001), we still found those compounds in all regencies and in most sediment samples.

Of the 20 substances, trans-chlordane, cis-chlordane, aldrin, dieldrin, 4,4' DDD, $\gamma \mathrm{HCH}$, and metolachlor were detected in $\geq 50 \%$ of the samples, whereas trans-chlordane and cis-chlordane were identified to be the most dominant of OCPs and quantified in $83 \%$ and $67 \%$ of the sediment samples, respectively (Fig. 2).

Among the selected regions, Brebes presented the highest total OCPs concentrations, ranging from $68.1 \pm 3.4$ to $168.1 \pm 9.8 \mu \mathrm{g} \mathrm{kg}^{-1}$ dw. Central Java is the main province of onion production in Indonesia (BPS, 2019), with Brebes Regency as the central production area, contributing to about 66\% of Central Java production in 2015-2016 (BPS, 2016). Because onions are very susceptible to pests, there is a widespread use of pesticides in this region to prevent and/or eradicate the pest, herb or fungi. That is why Brebes is considered as the regency with the largest pesticide usage both in Indonesia and in South-east Asia (Suhartono, 2018). In their previous work (Suhartono et al., 2012), found that farmers in this area spray the onions about 2-4 times a week in the dry season and even every day in the rainy season. 38 different commercial brands of pesticides ( 23 types of insecticides, 12 types of fungicides and 3 types of herbicides) are used in onion production. Moreover, in 2017 about 1300 of 3200 pesticide brands registered by the Ministry of Agriculture, Republic of Indonesia are marketed in Brebes Regency (Suhartono, 2018).
Pemalang area is ranked in the second highest for contamination among the four regencies, with total OCPs concentrations ranging between 45.8 and $118.1 \mu \mathrm{g} \mathrm{kg}^{-1} \mathrm{dw}$. In Central Java, Pemalang is one of the nine main Java paddy producer centers with an agricultural area of 34,457.49 Ha (Pemalang Regency, 2019). There are 14 pesticides used in Pemalang, and the dose of the use of pesticides in rice farming areas is the highest in Central Java with a frequency of use of 2-3 times each week (Ardiwinata and Nursyamsi, 2012; Bantarwati et al., 2013; Kurniasih et al., 2013). Through various channels, e.g. riverine run-off and atmospheric deposition, these compounds may find their ways into shrimp farming areas where they become deposited and trapped on surface sediment.

\subsection{Chlordanes (trans- and cis-chlordane), heptachlor and heptalochlor epoxyde}

In aquatic environment, chlordane is highly hydrophobic, and strongly associated with the organic carbon, clay and silt (Hirano et al., 2007). Chlordane is a ubiquitous and persistent pesticide, which was widely used for both agricultural and residential applications since its introduction in the 1940s (Ouyang et al., 2005). Although the use of chlordane was banned in the 1980s, it is still commonly detected in the aquatic system (Alam et al., 2014; Hirano et al., 2007).

With regard to the distribution of compounds belonging to the Chlordane family, heptachlore had the major contribution (63.3\% of ¿Chlordanes), followed by trans-chlordane (24.4\%), heptachlor epoxide (7.3\%), and cis-chlordane (4.9\%). Heptachlor, typically originates from technical chlordane, is also used as an insecticide (Baek et al., 2011). In order to evaluate the source of chlordane, we calculated the cis-chlordane/trans-chlordane ratios, based on work done by (Alam et al., 2014). The ratio was higher than 0.79 , suggesting that detected chlordane was historical and weathered

Table 1

Concentrations range of OCPs and PCBs ( $\mu \mathrm{g} \mathrm{kg-1} \mathrm{dw)} \mathrm{in} \mathrm{surface} \mathrm{sediments} \mathrm{of} \mathrm{shrimp} \mathrm{ponds} \mathrm{of} \mathrm{the} \mathrm{northern} \mathrm{coast} \mathrm{of} \mathrm{Central} \mathrm{Java.}$

\begin{tabular}{|c|c|c|c|c|c|}
\hline \multirow[t]{2}{*}{ Chemical Family } & \multirow[t]{2}{*}{ Compounds } & \multicolumn{4}{|c|}{ Range of concentration $\left(\mu \mathrm{g} \mathrm{kg}^{-1}\right)$} \\
\hline & & Brebes & Tegal & Pemalang & Pekalongan \\
\hline \multirow[t]{5}{*}{ Drins } & Aldrin & nd $-4.9 \pm 0.3$ & nd $-3.4 \pm 0.4$ & nd $-26.5 \pm 1.4$ & nd $-0.5 \pm 0.1$ \\
\hline & Dieldrin & nd $-10.7 \pm 0.4$ & $6.1 \pm 0.5-13.2 \pm 0.5$ & nd $-2.4 \pm 0.3$ & nd \\
\hline & Endrin & nd $-8.8 \pm 1.2$ & nd $-36.2 \pm 1.2$ & nd $-13.7 \pm 0.6$ & nd $-4.7 \pm 0.8$ \\
\hline & Endrin Aldehyde & nd & nd & nd & nd \\
\hline & Endrin Ketone & $0.31 \pm 0.1-0.8 \pm 0.1$ & nd & nd $-9.7 \pm 0.3$ & nd $-0.1 \pm 0.1$ \\
\hline \multirow[t]{4}{*}{ Chlordanes } & Heptachlore & nd $-20.7 \pm 0.9$ & nd & nd & nd \\
\hline & Heptalochlor epoxyde & nd $-1.8 \pm 0.3$ & nd $-0.6 \pm 0.1$ & nd & nd $-0.4 \pm 0.1$ \\
\hline & Cis-Chlordane & nd $-0.2 \pm 0.1$ & $0.2 \pm 0.1-0.6 \pm 0.1$ & nd $-0.4 \pm 0.1$ & nd $-0.1 \pm 0.1$ \\
\hline & Trans-Chlordane & nd $-0.1 \pm 0.1$ & $0.1 \pm 0.1-0.1 \pm 0.1$ & $0.03 \pm 0.01-0.1 \pm 0.01$ & nd $-10 \pm 0.9$ \\
\hline \multirow[t]{2}{*}{ Endosulfan } & Endosulfan I & nd $-31.7 \pm 1.6$ & nd & nd $-39.9 \pm 1.2$ & nd $-39.9 \pm 3.4$ \\
\hline & Endosulfan Sulfate & nd $-4.7 \pm 0.7$ & nd & nd & nd $-1.2 \pm 0.3$ \\
\hline \multirow[t]{3}{*}{ DDT } & $4,4^{\prime} \mathrm{DDD}$ & nd $-6.7 \pm 0.5$ & nd $-3.1 \pm 0.3$ & nd & nd $-6.7 \pm 0.8$ \\
\hline & $4,4^{\prime} \mathrm{DDE}$ & nd $-11.2 \pm 0.2$ & nd $-10.1 \pm 0.4$ & nd & nd \\
\hline & $4,4^{\prime} \mathrm{DDT}$ & nd $-2.8 \pm 0.3$ & nd & nd & nd $-0.3 \pm 0.1$ \\
\hline \multirow[t]{4}{*}{$\mathrm{HCHs}$} & $\alpha \mathrm{HCH}$ & nd $-23.1 \pm 1.3$ & nd & nd $-11.2 \pm 0.8$ & nd $-9.4 \pm 1.2$ \\
\hline & $\beta \mathrm{HCH}$ & $3.9 \pm 0.2-70.5 \pm 1.7$ & nd & nd $-4.0 \pm 0.4$ & nd $-5.7 \pm 0.7$ \\
\hline & $\gamma \mathrm{HCH}$ & nd $-7.1 \pm 0.9$ & nd $-7.1 \pm 0.4$ & nd $-7.8 \pm 0.9$ & nd $-3.8 \pm 0.6$ \\
\hline & $\delta \mathrm{HCH}$ & nd $-28.3 \pm 1.3$ & nd & nd $-16.8 \pm 0.7$ & nd $-10.5 \pm 1.0$ \\
\hline \multirow[t]{2}{*}{ Chloroacetanilide } & Alachlore & nd $-24.8 \pm 1.1$ & nd $-1.2 \pm 0.2$ & nd $-5.9 \pm 0.5$ & nd \\
\hline & Metolachlor & nd $-6.5 \pm 0.8$ & nd $-7.1 \pm 0.5$ & nd $-2.8 \pm 0.3$ & nd $-0.9 \pm 0.1$ \\
\hline \multirow{8}{*}{$\begin{array}{l}\Sigma \text { Total OCPs } \\
\text { PCBs }\end{array}$} & & $68.1 \pm 3.4-168.1 \pm 9.8$ & $31.1 \pm 6.4-48.4 \pm 5.9$ & $45.8 \pm 3.5-118.1 \pm 6.8$ & $7.8 \pm 2.6-51.5 \pm 4.1$ \\
\hline & РСВ 28 & nd $-0.1 \pm 0.05$ & nd & nd & nd \\
\hline & PCB 52 & $0.1 \pm 0.1-1.9 \pm 0.2$ & nd $-0.1 \pm 0.04$ & $0.1 \pm 0.02-3 \pm 0.2$ & $0.1 \pm 0.02-0.5 \pm 0.1$ \\
\hline & PCB 101 & $0.1 \pm 0.1-0.1 \pm 0.1$ & nd $-0.1 \pm 0.03$ & nd $-0.18 \pm 0.04$ & $0.1 \pm 0.1-0.3 \pm 0.1$ \\
\hline & РCB 118 & nd $-0.2 \pm 0.1$ & $0.2 \pm 0.1-2.2 \pm 0.3$ & nd $-0.9 \pm 0.1$ & nd $-0.9 \pm 0.2$ \\
\hline & РCB 138 & nd $-0.2 \pm 0.1$ & nd $-0.1 \pm 0.04$ & $0.1 \pm 0.02-0.2 \pm 0.1$ & $0.1 \pm 0.1-0.2 \pm 0.1$ \\
\hline & PCB 153 & nd $-0.2 \pm 0.1$ & nd $-0.14 \pm 0.03$ & nd $-0.2 \pm 0.03$ & $0.1 \pm 0.1-0.2 \pm 0.1$ \\
\hline & PCB 180 & $0.1 \pm 0.04-0.2 \pm 0.05$ & $0.1 \pm 0.03-0.26 \pm 0.1$ & $0.1 \pm 0.1-0.1 \pm 0.05$ & $0.1 \pm 0.04-0.1 \pm 0.02$ \\
\hline$\Sigma$ Total 7 PCBs & & $0.7 \pm 0.1-2.2 \pm 0.3$ & $0.7 \pm 0.1-3.6 \pm 0.4$ & $0.8 \pm 0.1-3.3 \pm 0.5$ & $0.6 \pm 0.1-2.2 \pm 0.2$ \\
\hline
\end{tabular}




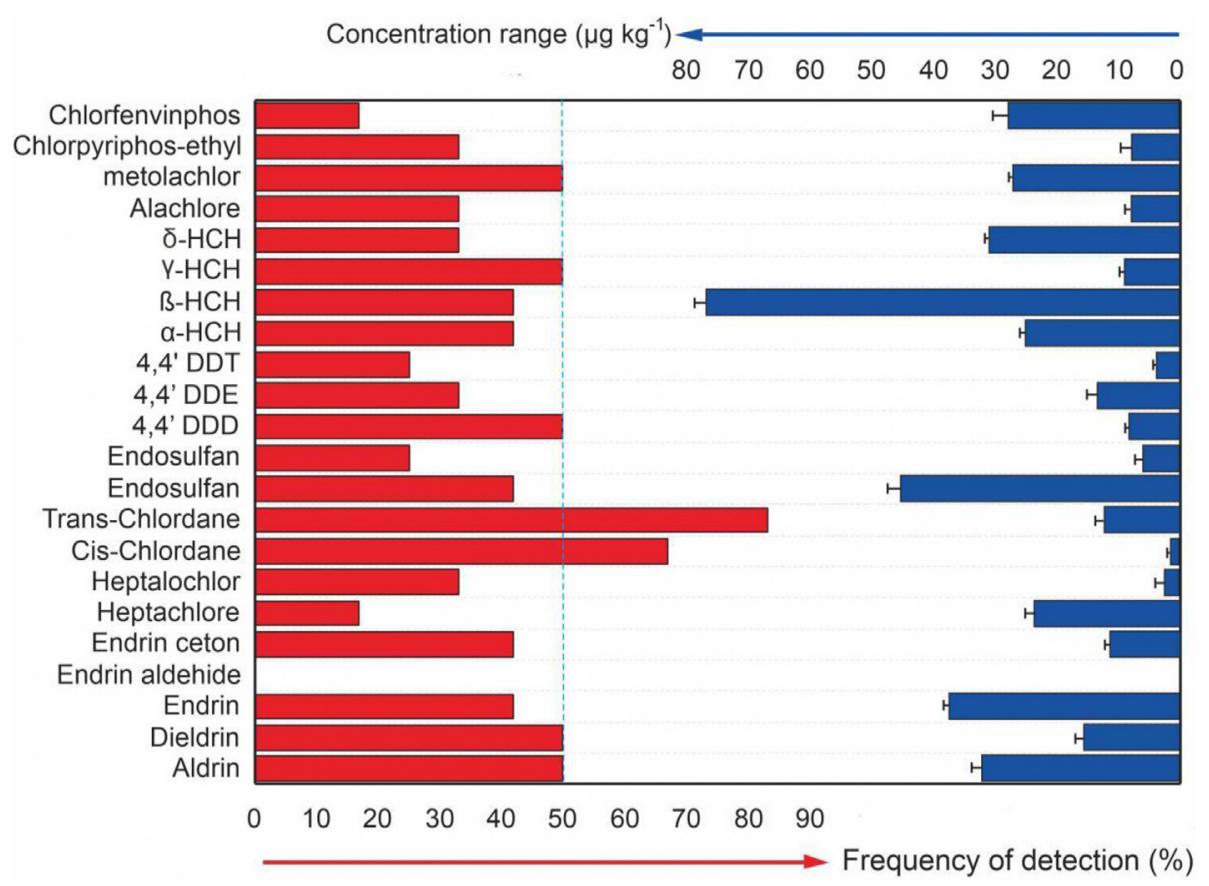

Fig. 2. The occurrence of OCPs in surface sediments of shrimp pond.

residues from commercial sources.

\section{4. $D D T s$}

According to Mueller et al. (2011), DDT was widely used for crop and livestock protection from the 1950s, whereas in residential, commercial and industrial area, DDT was applied for mosquito control. In the present study, overall, concentrations of $\sum$ DDTs in the northern part of the Central Java coast were lower than those reported from sediment of shrimp mariculture farm in Hongkong, from 9.95 to $44.4 \mu \mathrm{g} \mathrm{kg}-1$ with an average of $23.9 \mu \mathrm{g} \mathrm{kg}-1$ (Wang et al., 2014), but higher than those from sediment of Jincheng Bay mariculture area, China, in a concentration range from 4.1 to $6.7 \mu \mathrm{g}$ kg-1 (Hu et al., 2015).

Brebes region, which is essentially an agricultural area, presents the highest concentration in DDT, with values ranging between $4.2 \pm 0.4-16.3 \pm 1.1 \mu \mathrm{g} \mathrm{kg}^{-1} \mathrm{dw}$ with an alarming average of about $10.0 \pm 6.05 \mu \mathrm{g} \mathrm{kg}{ }^{-1} \mathrm{dw}$. However, these alarming concentrations were lower than those found in agriculture and shellfish farming area of Babitonga Bay, Southern Brazil. In this area, the DDTs were the predominant OCP group, with concentrations ranging from below detection limits to $122 \mu \mathrm{g} \mathrm{kg}^{-1} \mathrm{dw}$ (Rizzi et al., 2017).

$4,4^{\prime}$-DDE is the main metabolite of DDT detected in sediment samples in Brebes (below detection limit $-11.2 \pm 0.2 \mu \mathrm{g} \mathrm{kg}-1 \mathrm{dw}$ ) and Tegal (below detection limit $-10.1 \pm 0.4 \mu \mathrm{g} \mathrm{kg}-1 \mathrm{dw}$ ). These values are lower than those detected in sediment samples taken in the surrounding areas of shrimp ponds in Jiquilisco Bay, El Salvador, ranging from $3.8 \mu \mathrm{g} \mathrm{kg}^{-1}$ to $30.9 \mu \mathrm{g} \mathrm{kg}^{-1}$ (Nomen et al., 2012). 4,4' DDE is strongly adsorbed to sediment and is very persistent in aquatic environment. DDT isomers can biodegrade under aerobic conditions to DDE and anaerobic conditions to p,p'-DDD in the environment (Bopp et al., 1982; ATSDR, 2002; Hu et al., 2010; Zhang et al., 2014). Therefore, when DDD/DDE $<1$, DDT undergoes aerobic biodegradation, and when DDD/DDE $>1$, DDT undergoes anaerobic biodegradation (Liu et al., 2008). In sediment samples from Brebes and Tegal, the ratio of $4,4^{\prime}$-DDE, to $4,4^{\prime}$-DDD was smaller than 1 , thereby suggesting mainly aerobic degradation.
DDTs ratio was previously used as an indicator of the residence time of DDT in the environment (Olisah et al., 2019). The values of DDT ratios in surface sediments fewer than 1 in Brebes region (Table 2) suggests that the residues are mainly originated from historical usage rather than a recent application.

A similar result was recently found in the aquaculture area in Cau Hai lagoon, Vietnam (Tran et al., 2019). It is not possible to calculate the DDT/DDE ratio in Tegal region since the parent pesticide $4,4^{\prime}$-DDT was not detected, but the presence of 4,4-DDE and $4,4^{\prime}$-DDD suggests a lack of recent inputs of the pesticide.

\section{5. $\mathrm{HCHs}(\alpha-, \beta-$, and $\gamma-\mathrm{HCH})$}

$\mathrm{HCHs}$ is present in all samples, whatever the region, with average concentrations of $4.1 \pm 3.7$ (Pekalongan) to a concerning value of $54.7 \pm 18.5 \mu \mathrm{g} \mathrm{kg}^{-1} \mathrm{dw}$ found in Brebes. Globally, the composition of $\mathrm{HCHs}$ congener profiles in surface sediments was, $\beta$ $\mathrm{HCH} 33.2 \pm 7.2 \%, \alpha-\mathrm{HCH} 27.6 \pm 3.2 \%, \gamma-\mathrm{HCH} 13.3 \pm 1.1 \%$ and $\delta-\mathrm{HCH}$ $25.9 \pm 3.5 \%$. The predominance of the $\beta$-isomer can be explained by the environmental transformation of $\alpha-\mathrm{HCH}$ and $\gamma-\mathrm{HCH}$ into $\beta-\mathrm{HCH}$ (Maldonado and Bayona, 2002). Moreover, among HCHs isomers, $\beta$ isomer is the most persistent in the environment and tends to accumulate in sediments (Doong et al., 2002). Since the $\beta-\mathrm{HCH}$ isomer is relatively resistant with respect to microbial degradation

Table 2

Diagnostic ratios of DDTs, HCHs, and chlordanes in shrimp pond sediments.

\begin{tabular}{lllll}
\hline Region & Brebes & Tegal & Pemalang & Pekalongan \\
\hline$\alpha-H C H$ to $\beta-H C H$ & 0.6 & NA & 2.8 & 1.7 \\
$\alpha-H C H$ to $\gamma-H C H$ & 4.1 & NA & 2.7 & 1.7 \\
$\beta-H C H / H C H s$ & 0.5 & NA & 0.1 & 0.2 \\
$\gamma-\mathrm{HCH} / \mathrm{HCHs}$ & 0.1 & 1 & 0.1 & 0.2 \\
$\% \beta-\mathrm{HCH}$ & 48.0 & 0.0 & 10.9 & 18.2 \\
$\% \gamma-\mathrm{HCH}$ & 6.8 & 100.0 & 11.3 & 17.7 \\
$C C / T C$ & 3.5 & 5.0 & 6.8 & 7.3 \\
$D D T /(D D E+D D D)$ & 0.1 & 0.0 & 0.0 & 0.0 \\
\hline
\end{tabular}

NA: Not Applicable. 
and has the lowest volatility, predominance of $\beta-\mathrm{HCH}$ in sediment samples is probably indicative of local contamination by technical $\mathrm{HCH}$ (Li, 1999) and/or indicates a historical usage in industry and agriculture (Doong et al., 2002).

Brebes is the region with the highest level of HCHs. It is worth since, beside Pemalang, Brebes is one of the main paddies and onion centers of production in Central Java. It is interesting to note that Zhang et al. (2018) reported that paddy fields are one of possible HCHs source in the Southeast of China. Besides, Wang et al. (2014), who studied for aquaculture-derived OCPs contamination in coastal sediments, showed that aquaculture could cause significant enrichment in OCPs. In mariculture surface sediments (0-5

cm), concentrations of $\sum_{1.3}$ HCHs and $\sum_{\text {H.f DDTs were approxi-mately }}$ reference sites. The authors hypothesized that major sources for these enrichments was the use of OCPs contaminated fish feeds.

Around the world, $\mathrm{HCH}$ is available in two formulations: technical HCHs and lindane. Technical HCHs contained $60-70 \% \alpha-\mathrm{HCH}$, $5-12 \% \beta-\mathrm{HCH}, 10-15 \% \gamma-\mathrm{HCH}$ and $6-10 \% \delta-\mathrm{HCH}(\alpha / \gamma-\mathrm{HCH}$ ranging $3-7)$, while lindane consists of almost pure $\gamma-\mathrm{HCH}(>99 \%)$ (Barhoumi et al., 2019; Walker et al., 1999). Concerning the present work, the sources of $\mathrm{HCH}$ were evaluated using the isomeric ratios described in material and methods section. The ratio of $\alpha-\mathrm{HCH} / \gamma-$ $\mathrm{HCH}$ in Brebes was 4.1, suggesting technical $\mathrm{HCHs}$ as the possible source, which is consistent with the percentage of $\beta-\mathrm{HCH}$ (more than $5-14 \%$ ). This latter result suggested the contamination of shrimp pond sediments by technical $\mathrm{HCH}$. If there were no fresh inputs of technical $\mathrm{HCH}, \beta-\mathrm{HCH}$ would be predominant in most sediments. Last, in Brebes, $\beta-\mathrm{HCH}$ was predominant (47\%), indicating there is no fresh inputs of technical HCH (Tang et al., 2020). In contrast, the ratio of $\alpha-/ \gamma-\mathrm{HCH}$ in Pekalongan and Pemalang was below 4 , with $\alpha-\mathrm{HCH}$ as predominant isomer. This latter result suggested the use of pure lindane for an agricultural purpose instead of technical HCHs (Tang et al., 2020). It is worthy to note that the production and use of lindane for agricultural purpose has been banned in Indonesia since 2009. These finding results highlight the long-term persistence of these compounds in sediment matrices.

\subsection{The occurrence of polychlorinated biphenyl (PCBs)}

Based on the recommendations of the International Council for the Exploration of the Sea (ICES) (Webster et al., 2013) and (OSPAR, 2001), this study focused on the set of seven indicator PCB congeners (PCBs 28, 52, 101, 118, 138, 153, and 180) which are used as marker congeners for PCB monitoring and regulation in the USA and Europe. Results for the sum of 7 congeners and individual PCB concentrations ( $\mu \mathrm{g} \mathrm{kg}^{-1} \mathrm{dw}$ ) in superficial sediments from shrimp ponds in the northern coast of Central Java are displayed in the bottom of Table 1. Total PCBs concentrations in the different ponds ranged from $0.6 \pm 0.1$ to $3.6 \pm 0.4 \mu \mathrm{g} \mathrm{kg}^{-1}$, with a grand average of $1.7 \pm 1.1 \mu \mathrm{g} \mathrm{kg}^{-1}$. This concentration of total PCBs was slightly lower than those reported worldwide in other aquaculture sediments, e.g. the concentration of PCBs in surface sediment of aquaculture areas in New Brunswick, Canada (1.07-10.4 ng g ${ }^{-1}$ ) (Sather et al., 2006), mariculture area along the coast of Hong Kong and mainland China (5.10-11.0 ng g ${ }^{-1}$, mean $7.96 \mathrm{ng} \mathrm{g}^{-1}$ ) (Wang et al., 2011), Xiangshan Bay, China $\left(15.2 \mu \mathrm{g} \mathrm{kg}^{-1}\right.$ ) (Lin et al., 2020). Finally, in the present work, the PCB levels in mariculture surface sediments of the shrimp farms were relatively low.

Fig. 3 presents the frequency of detection of the 7 PCBs indicators and PCBs homolog. The PCB homolog distribution indicated that the relative composition of the $\mathrm{PCB}$ congeners was dominated by tetra- $\mathrm{Cl}$ PCB in Brebes and Pemalang, representing $54 \%-62 \%$ of the total PCBs. Zhang et al. (2008) reported that such homolog was widely present in atmosphere for higher volatility. Furthermore, Totten et al. (2004) and Gioia et al. (2008) demonstrated that PCB concentration levels in the lower atmosphere near the water are sustained by tetra-Cl PCBs volatilized from the upper water layer. Dechlorination of highly chlorinated congeners with anaerobic microbes occurs in the sediments also the possible factor which contributes to the high proportion of light PCBs (Boyle et al., 1992), as reported by Zhong et al. (2020) in the eastern Gaizhou Beach and the coastal area adjacent to Erjie ditch, which is the inputs of PCBs from atmospheric depositions and microbial degradation.

Tegal and Pekalongan have a similar compositional pattern with predominant penta-PCBs (CB101 and CB118) in the shrimp pond sediments. The presence of penta- $\mathrm{Cl}$ PCBs represented the commercial PCBs derived from erosion of contaminated soils transported to the aquatic system by surface runoff (Zhong et al., 2020). Those PCB homologs are predominant in the Aroclor 1254 mixtures with an average chlorine content of 54\% (IARC and WHO, 2016; USEPA, 2017). The similar pattern was found in Shuangtaizi Estuary, China (Yuan et al., 2015).

A PCA was used to obtain further information on PCB compositions and sources by comparing samples and commercial mixtures (Aroclor 1242, 1248, 1254, 1260). Homolog percent concentrations were used (Frignani et al., 2007) (BMI; GeoChem Metrix. Inc.; U.S.Navy SPAWAR; USEPA, 2017), with a standardization of concentrations was first applied. The score plot obtained from the first two principal components, which together explain $82.4 \%$ of the total variance is shown in Fig. 4.

Pemalang and Brebes are grouped around Aroclor 1248 (where tetra- $\mathrm{Cl}$ was the most abundant components), while Tegal and Pekalongan showed similarity with Aroclor 1254 (with a significant contribution of penta-Cl). Aroclor 1254 was the technical mixture with the widest range of industrial applications and was the most widely used. Aroclor 1254 was used in electrical equipment like capacitors and transformers, but also as hydraulic fluids, plasticizers, adhesives, wax and pesticide extenders, inks, cutting oils, metal coatings, sealants and caulking compounds (ATSDR, 2000; Wischkaemper et al., 2013).

Tegal is the regency with many metal manufacturing industries, as well as metal smelting industry. Fitriyani et al. (2017) reported that in 2011 there was serious hazardous waste pollution coming from the metal smelting industry in Tegal. The metallurgy industry and smelting process was considered the main sources of dioxinlike PCBs in Korea (Yu et al., 2006) and Portugal (Antunes et al., 2012). Limestone burning industry (cement production) by utilization of used oil in Tegal also reported as one of hazardous waste source in Tegal (DLH and Tegal, 2014). Susanto et al. (2016) characterized used oil on lime production plant, and they found that Aroclor 1254 and Aroclor 1248 were existed. Atmospheric emissions during fuel combustion might also generate PCBs since in the burning process, the used oil was heated on a preheater at $46-70{ }^{\circ} \mathrm{C}$ and then injected to the burning oven at $850-960{ }^{\circ} \mathrm{C}$ (Susanto et al., 2016). Thus, both of used oil and fuel combustion were assumed to be the other sources of PCBs in Tegal, as reported by Liu et al. (2018) who found that thermal processes (incineration) associated to unintentionally produced PCBs in China.

\subsection{Comparison with sediment quality guidelines}

The concentrations of targeted compounds were then compared to threshold concentrations from sediment-quality guidelines (SQG) to evaluate the possible ecological risks associated with OCPs (Table 3). The SQG adopted were constituted by Threshold-Effects Level (TEL), Probable-Effects Level (PEL), Effects Range-Low (ERL) and Effects Range-Medium (ERM). The TEL represents the 

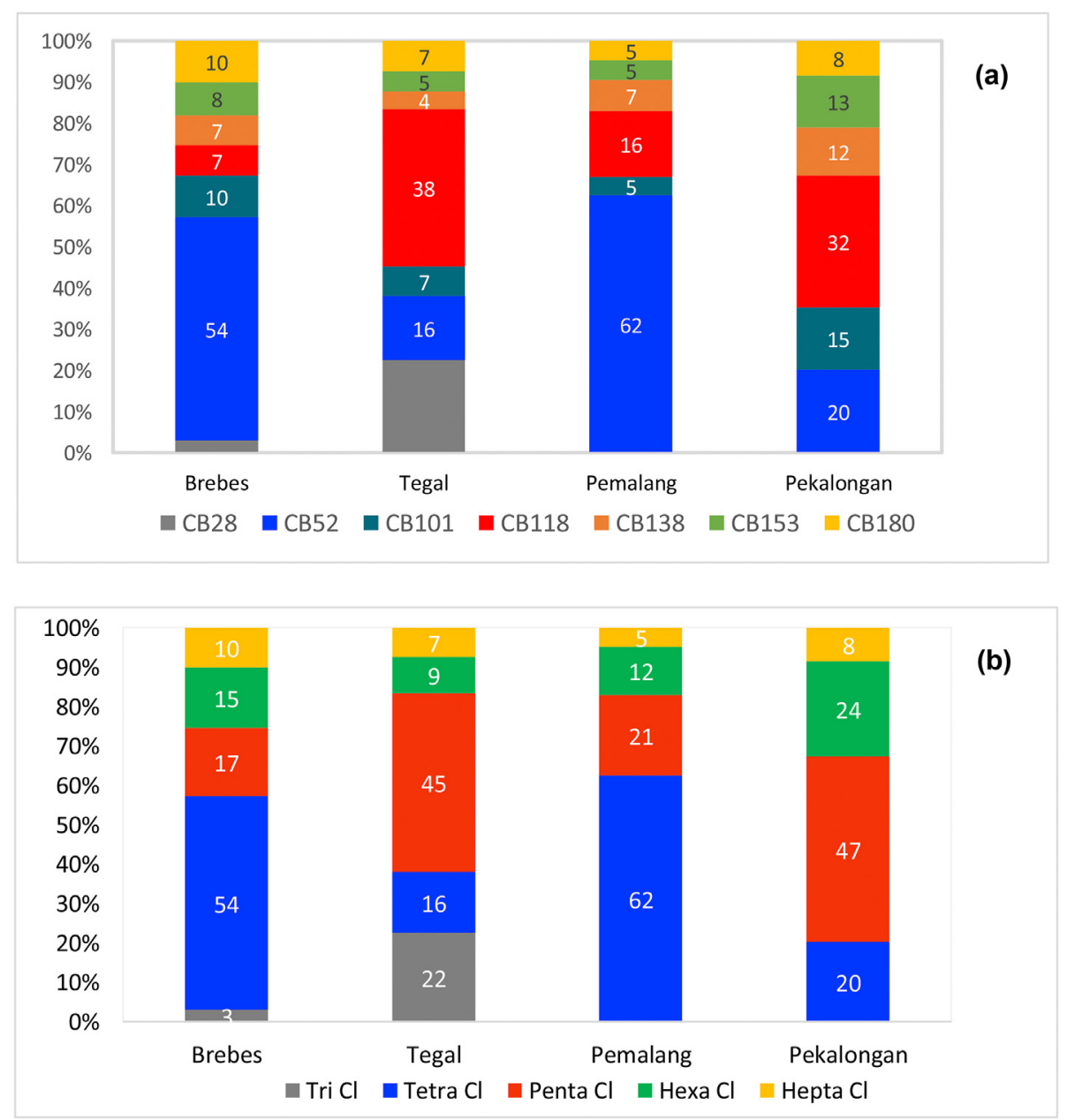

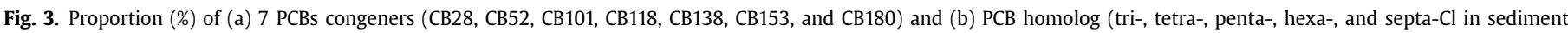
samples.

concentration below which adverse biological effects are expected to occur rarely. The PEL represents the level above which adverse effects are expected to occur frequently. The ERL is indicative of concentrations below which adverse effects rarely occur and ERM defines the level above which adverse effects are expected to occur frequently (CCME and Environment, 1999; Long and MacDonald, 1998; Long et al., 1995; Macdonald et al., 1996; NOAA and Administration, 2008).

In Brebes, the area with the highest concentration of POPs (i.e. dieldrin, endrin, 4,4'-DDD and 4,4'-DDT) have the potential to occasionally cause ecological impacts as their average concentrations were greater than TEL, but below PEL. Whereas heptalochlor epoxyde, 4, $4^{\prime}$-DDE, and $\gamma-\mathrm{HCH}$ present in the concentration above PEL, indicate these substances could cause adverse ecological impacts. $\Sigma$ chlordane presents in the concentration above both PEL and ERM in Brebes, suggesting potential ecological risk.

$\mathrm{HCH}$ was widely used in agriculture to control crop pests and mainly on rice paddies (Li, 1999). In this study, the $\sum$ HCHs was defined as the sum of $\alpha-\mathrm{HCH}, \beta-\mathrm{HCH}, \gamma-\mathrm{HCH}$ and $\delta-\mathrm{HCH}$. As shown in Table 1, the highest concentrations of $\sum \mathrm{HCHs}$ occurred in Brebes Regency, ranged from $34.4 \pm 2.3-70.5 \pm 6.4 \mu \mathrm{g} \mathrm{kg}-1$ with a mean of $54.7 \pm 18.4 \mu \mathrm{g} \mathrm{kg}-1$. those values were greater than those concentrations of $\sum \mathrm{HCHs}$ in surface sediments under mariculture facilities in Hongkong, ranged from 5.6 to $20.4 \mathrm{ng} \mathrm{g}^{-1}$ with a mean of $13.2 \mathrm{ng} \mathrm{g}^{-1}$ (Wang et al., 2014) and Jincheng Bay mariculture area,
China with the concentration of total HCHs range from 5.52 to $9.43 \mu \mathrm{g} \mathrm{kg}-1$ (Hu et al., 2015).

The use of technical $\mathrm{HCH}$ had been reduced over the world since technical $\mathrm{HCH}$ was substituted by lindane (over $90 \%$ is $\gamma-\mathrm{HCH}$ ). Among HCHs, $\gamma-\mathrm{HCH}$ (lindane) was found in at least one station of each region, at levels from below detection limits to $7.8 \mu \mathrm{g} \mathrm{kg}-1$, with a mean concentration $(\mu \mathrm{g} \mathrm{kg}-1)$ of $3.7 \pm 3.5 ; 4.1 \pm 3.7$; $1.8 \pm 1.9 ; 2.6 \pm 4.5$ respectively for Brebes, Tegal, Pekalongan, and Pemalang. Those values exceeded thresholds of $0.99 \mu \mathrm{g} \mathrm{kg}-1$ set by various institutions (CCME and Environment, 1999; FDEP, 1994; Long and MacDonald, 1998; Long et al., 1995; Macdonald et al., 1996; NOAA and Administration, 2008). In the light of the findings, contaminations of lindane is still a worrying problem in some aquaculture areas in the northern coast of Central Java.

Concerning DDT, the concentrations of $\sum$ DDTs from 12 stations ranged from below detection limit to $16.3 \pm 1.7 \mu \mathrm{g} \mathrm{kg} 1$, with the highest concentration found again in Brebes Regency, ranged from $4.2 \pm 0.9-16.3 \pm 1.7 \mu \mathrm{g} \mathrm{kg}-1$ and a mean of $10 \pm 6.1 \mu \mathrm{g} \mathrm{kg}-1$. Those values were significantly higher than TEL value of $3.89 \mu \mathrm{g} \mathrm{kg}-1$ and lower than PEL value of $51.7 \mu \mathrm{g} \mathrm{kg}-1$ set by the Canadian Council of Ministers of the Environment (CCME and Environment, 1999) and Florida Department of Environmental Protection (FDEP, 1994). It indicates that DDT concentration in Brebes Regency has the potential to cause adverse biological effects.

Regarding PCBs, compared to the sediment quality guidelines 

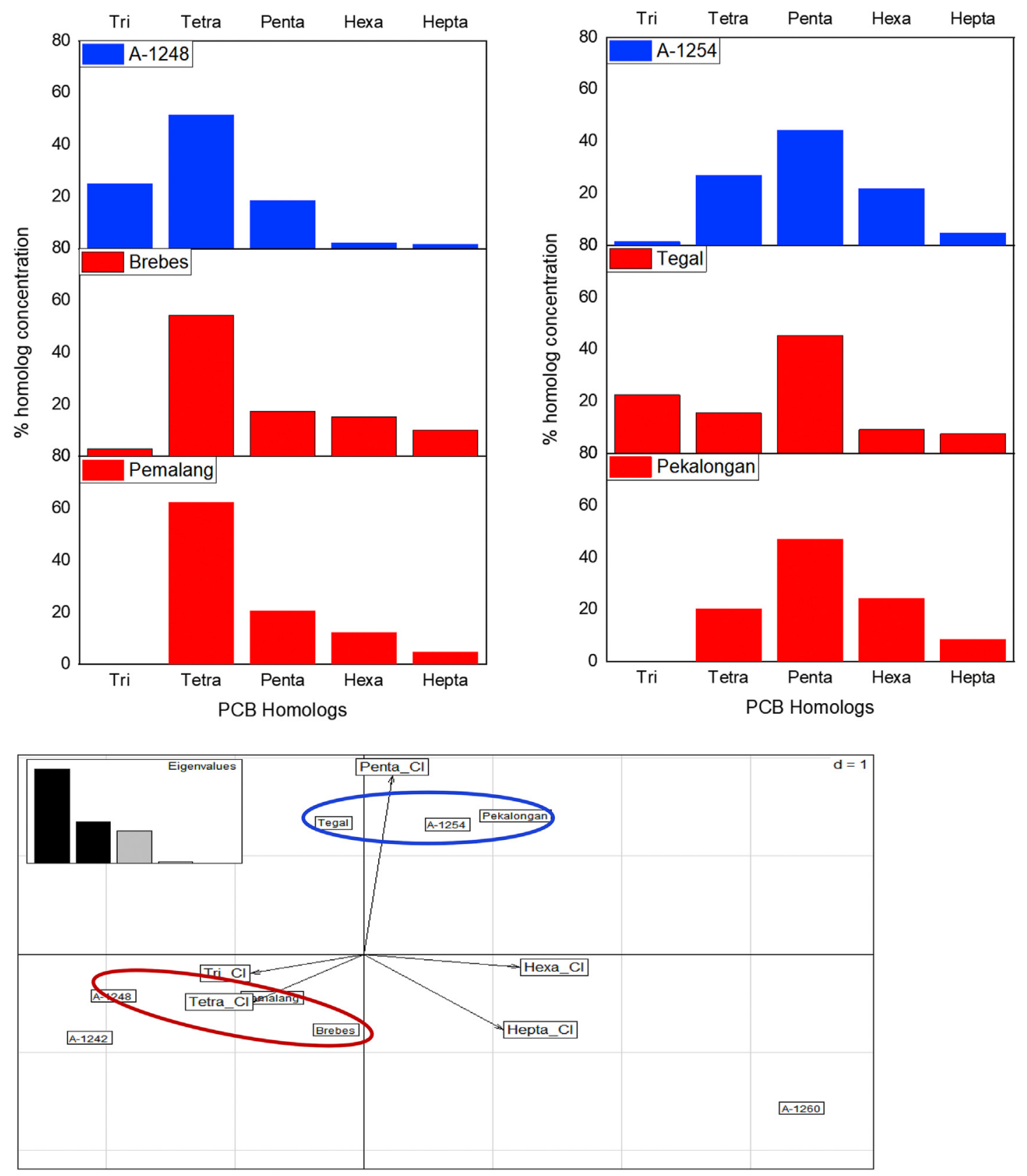

Fig. 4. Comparison of $\mathrm{PCB}$ compositions of sediments with those of commercial mixtures.

Table 3

Sediment Quality Guidelines (SQGs) (CCME and Environment, 1999) and the average concentrations of OCPs in surface sediments.

\begin{tabular}{|c|c|c|c|c|c|c|c|c|}
\hline \multirow[t]{2}{*}{ Compounds } & \multicolumn{4}{|c|}{ SQGs $\left(\mu \mathrm{g} \mathrm{kg}^{-1} \mathrm{dw}\right)$} & \multicolumn{4}{|c|}{ Average of Concentration ( $\mu \mathrm{g} \mathrm{kg}^{-1} \mathrm{dw}$ ) } \\
\hline & TEL & PEL & ERL & ERM & Brebes & Tegal & Pekalongan & Pemalang \\
\hline Dieldrine & 0.71 & 4.3 & 0.02 & 8 & $3.60 \pm 6.11$ & $6.43 \pm 6.59$ & n.d. & $1.42 \pm 1.26$ \\
\hline Endrine & 2.67 & 62.4 & n.a. & n.a. & $2.92 \pm 5.07$ & $19.83 \pm 18.26$ & $1.59 \pm 2.68$ & $4.57 \pm 7.92$ \\
\hline Heptalochlor epoxyde & 0.6 & 2.74 & n.a. & n.a. & $8.96 \pm 10.6$ & n.d. & n.d. & n.d. \\
\hline$\Sigma$ chlordane & 2.26 & 4.79 & 0.5 & 6 & $9.72 \pm 11.79$ & $0.58 \pm 0.64$ & $3.59 \pm 5.99$ & $0.27 \pm 0.21$ \\
\hline $4,4^{\prime} \mathrm{DDD}$ & 1.22 & 7.81 & 2 & 20 & $3.36 \pm 3.36$ & $1.22 \pm 1.62$ & $0.33 \pm 0.32$ & n.d. \\
\hline $4,4^{\prime} \mathrm{DDE}$ & 2.07 & 3.74 & 2.2 & 27 & $5.12 \pm 5.63$ & $5.93 \pm 5.26$ & n.d. & n.d. \\
\hline $4,4^{\prime} \mathrm{DDT}$ & 1.19 & 4.77 & 1 & 7 & $1.52 \pm 1.40$ & n.d. & $0.11 \pm 0.19$ & n.d. \\
\hline$\Sigma$ DDT & 3.89 & 51.7 & 1.58 & 46.1 & $10.0 \pm 6.05$ & $7.15 \pm 5.67$ & $0.44 \pm 0.18$ & n.d. \\
\hline$\gamma \mathrm{HCH}$ & 0.32 & 0.99 & n.a. & n.a. & $3.7 \pm 3.53$ & $4.09 \pm 3.67$ & $1.84 \pm 1.89$ & $2.6 \pm 4.5$ \\
\hline$\Sigma$ of 7 PCBs & 21.6 & 22.7 & 189 & 180 & $3.9 \pm 0.8$ & $6.7 \pm 1.4$ & $6.5 \pm 1.3$ & $3.7 \pm 0.8$ \\
\hline
\end{tabular}

TEL (Threshold-Effects Level); PEL (Probable-Effects Level); ERL (Effects Range-Low); ERM (Effects Range-Median); n.a. (No available); n.d. (Not detected). 
from Canada (CCME and Environment, 1999), the concentration of $\sum 7$ PCBs were below the concentration which potentially caused an ecological risk. Nevertheless, since the contaminants associated with sediments can accumulate in aquatic organisms (Voorspoels et al., 2004; Zhao et al., 2009), it is essential to monitor POPs level and their potential accumulation in the aquatic organism as well as in the aquatic environment.

Guo et al. (2008) and Liu et al. (2016) evaluate the contamination of OCPs in marine shrimp and the result affirmed that marine shrimp could accumulate the OCPs. Furthermore, Zhang et al. (2014) in their work on bioaccumulation of PCBs in aquatic biota (fish and shrimp) demonstrated a strong bioaccumulation of some OCPs by fish and shrimp. They found biota-sediment accumulation factors (BSAF) values for shrimp of about 0.12 for $\mathrm{HCHs}, 0.26$ for heptachlor, 0.4 for drins (dieldrin and endrin), and 3.4 for p,p'-DDD, and 1.9 for DDTs. Such BSAF values, associated with concentrations found in this study suggest potential accumulated DDTs value of $19.0 \mu \mathrm{g} \mathrm{kg}^{-1} \mathrm{dw}$ and $\mathrm{HCHs}$ value of $6.84 \mu \mathrm{g} \mathrm{kg}^{-1} \mathrm{dw}$ in shrimp in Brebes. By using the conversion factor of 2.8 to convert dry weight to fresh weight (FAO and Statistics, 2004), those values correspond to $6.79 \mu \mathrm{g} \mathrm{kg}^{-1}$ wet weight (ww) of DDTs and $2.44 \mu \mathrm{g} \mathrm{kg}^{-1} \mathrm{ww}$ of HCHs.

Jaikanlaya et al. (2009) detected the presence of PCBs in shrimp from the Eastern Coast of Thailand, and they highlighted the levels of PCBs in shrimp was three times higher than that in mussels and oysters. Previously, Tatem (1986) demonstrated that shrimp has an ability in the accumulation of PCBs (specifically Aroclor 1254) from sediment, with biota-sediment accumulation factors (BSAF) value ranged from 0.11 to 0.90 for Aroclor 1242 and 0.20 to 2.40 for Aroclor 1254. McLeese et al. (1980) also reported BSAF value for shrimp exposed to PCB mixed with either a muddy or sandy sediment, ranged from 3.6 to 10.9. A recent research by Lin et al. (2020) showed that the BSAF value of the $\sum 7$ PCBs for shrimp was 8.84 in Xiangshan Bay, China, indicating that the organism was readily subjected to bioaccumulation of PCBs from sediments. Compared to the result of $\sum 7$ PCBs concentration found in this study, the estimated concentration in shrimp will be $19.8 \pm 12.7 \mu \mathrm{g} \mathrm{kg}^{-1}$ and $19.3 \pm 11.5 \mu \mathrm{g} \mathrm{kg}^{-1}$ in Tegal and Pemalang, respectively. A worrying concentration found for the most toxic of 7 PCBs, i.e. PCB118, in terms of BASF value, since Lin et al. (2020) demonstrated that PCB 118 was more accumulated in organisms, with the value of 111.1. In addition, PCB 118 was detected in all regions, and among PCBs, it presented as the highest detected PCB level in Tegal.

Considering results of this study, it should be noticed since seafood being the one of main source of food for many people in Central Java. Thus, given the high amount of seafood (e.g. shrimp) consumption (20.67 g/person/day) (BPS, 2016), it is essential to monitor the levels of POPs and other dioxin like compounds both in sediments and shrimps and thus validate or invalidate literature BASF for OCPs and PCBs in L. vannamei. Thereby, the possible risks for humans of PCBs and related compounds via consumption of local seafood can be determined. In addition, we found that CB118, a mono-ortho-chlorinated PCBs (MO-PCBs), was the secondhighest level of PCBs. From a toxicological point of view, most attention is being paid to those $\mathrm{PCB}$ congeners that produce a similar toxicity to that of 2,3,7,8-tetrachlorodibenzo-p-dioxin (TCDD), and they are commonly known as dioxin-like PCBs (dlPCBs). Considerable dioxin-like toxicity is also attributed to PCB 118 , with toxic equivalency factors (TEFs) of 0.00003 set by WHO (Van den Berg et al., 2006).

\section{Conclusion}

Brebes Regency presents the highest total OCPs concentrations, followed by Pemalang, Tegal, and Pekalongan Regencies. We assumed that paddy and onion production in Brebes maybe the main possible apportionment of pesticides which are intensively used in this region to mitigate the pest, herb or fungi. For other regencies, intensive urban used of pesticides may cause the occurrence of the OCPs. Concerning PCBs, our data showed in

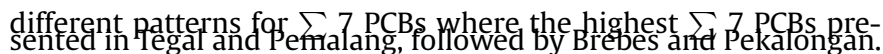
The most toxic PCB congener, PCB 118, was detected in all four studied regions (Brebes, Tegal, Pemalang and Pekalongan), with the highest proportion found in Tegal. The congener distribution patterns in these samples indicate the dominance of light chlorinated homologs (tetra- and penta-Cl PCBs). Based on homolog composition analysis, we hypothesized that the presence of PCBs in these regions derived from Aroclor 1248 and Aroclor 1254. In summary, surface sediment contamination in aquaculture system by OCPs and PCBs appeared to potentially cause an adverse effect to the living biota when referencing the sediment quality guidelines (SQGs) approach. Furthermore, we determined the potential accumulated of OCPs and PCBs in the shrimp muscle with the value of about $19 \mu \mathrm{g} \mathrm{kg}^{-1} \mathrm{dw}$ for $\Sigma$ DDTs and $6.8 \mu \mathrm{g} \mathrm{kg}^{-1} \mathrm{dw}$ of $\Sigma \mathrm{HCHs}$ in Brebes. Concerning PCBs, we found the highest potential accumulation of $\Sigma 7$ PCBs in shrimp muscle of $19.8 \mu \mathrm{g} \mathrm{kg}^{-1} \mathrm{dw}$ and $19.3 \mu \mathrm{g} \mathrm{kg}^{-1} \mathrm{dw}$ in Tegal and Pemalang, respectively. Even though the results revealed a risk of accumulation, potential level of POPs in shrimp muscle were below the maximum residue limits set by FDA (FDA, 2020).

In the light of above, it should be underlined the importance of continuous and effective POPs monitoring activities. It appears necessary to measure the levels of these pollutants in both sediment and shrimps. This will enable the validation or invalidation of the biota-sediment accumulation factors (BSAF) of the literature. This will finally allow an objective risk assessment for human health for shrimp consumers in turn to take appropriate preventive measures. This will be done soon in a further work.

\section{Credit author statement}

Nuning Vita Hidayati: Investigation, Writing - original draft. Laurence Asia: Methodology on sampling and Formal analysis. Imen Khabouchi: Methodology on sampling and Formal analysis. Franck Torre: statistical Formal analysis Conceptualization. Ita Widowati: Supervision. Agus Sabdono: Supervision. Pierre Doumenq: Conceptualization, writing-rewriting, Validation. Agung Dhamar Syakti: Conceptualization, Supervision, writing-reviewing and editing, corresponding authors.

\section{Declaration of competing interest}

The authors declare that they have no known competing financial interests or personal relationships that could have appeared to influence the work reported in this paper.

\section{Acknowledgement}

We thank the Indonesian Endowment Fund for Education (LPDP) and the Ministry of Finance and the Directorate General of Higher Education (DEIRJEN DIKTI) for providing scholarship and research support. First author also expresses her gratitude to the Laboratoire de Chimie de L'Environnement (LCE) - AMU, where the data reported in this paper was derived. 


\section{References}

Alam, M.J., Daoxian, Y., Jiang, Y.J., Yuchuan, S., Yong, L., Xin, X., 2014. Sources and transports of organochlorine pesticides in the Nanshan underground river, China. Environmental Earth Sciences 71, 1977-1987. https://doi.org/10.1007/ s12665-013-2919-5.

Antunes, P., Viana, P., Vinhas, T., Rivera, J., Gaspar, E.M.S.M., 2012. Emission profiles of polychlorinated dibenzodioxins, polychlorinated dibenzofurans (PCDD/Fs), dioxin-like PCBs and hexachlorobenzene (HCB) from secondary metallurgy industries in Portugal. Chemosphere 88, 1332-1339. https://doi.org/10.1016/ j.chemosphere.2012.05.032.

Ardiwinata, A., Nursyamsi, D., 2012. Pesticide residues at rice production centers in central Java. Jurnal Pangan 21, 39-58. https://doi.org/10.33964/jp.v21i1.103.

Ashraf, M.A., 2017. Persistent organic pollutants (POPs): a global issue, a global challenge. Environ. Sci. Pollut. Res. Int. 24, 4223-4227. https://doi.org/10.1007/ s11356-015-5225-9.

ATSDR, 2000. Toxicological Profile for Polychlorinated Biphenyls (PCBs). Public Health Service - Agency for Toxic Substances and Disease Registry, Atlanta, Georgia, p. 765.

Baek, S.-Y., Choi, S.-D., Chang, Y.-S., 2011. Three-year atmospheric monitoring of organochlorine pesticides and polychlorinated biphenyls in polar regions and the South pacific. Environ. Sci. Technol. 45, 4475-4482. https://doi.org/10.1021/ es1042996.

Bantarwati, D., Suhartono, Suwondo A., 2013. The association between pesticide exposure and hypothyroidism incidence on group of women at childbearing age in agricultural area of gombong village, belik, Pemalang. Jurnal Kesehatan Lingkungan Indonesia 12. https://doi.org/10.14710/jkli.12.2.138\%20-\%20143.

Barhoumi, B., Beldean-Galea, M.S., Al-Rawabdeh, A.M., Roba, C., Martonos, I.M., Balc, R., Kahlaoui, M., Touil, S., Tedetti, M., Driss, M.R., Baciu, C., 2019. Occurrence, distribution and ecological risk of trace metals and organic pollutants in surface sediments from a Southeastern European river (Somesu Mic River, Romania). Sci. Total Environ. 660, 660-676. https://doi.org/10.1016/ j.scitotenv.2018.12.428.

Bergamaschi, B.A., Tsamakis, E., Keil, R.G., Eglinton, T.I., Montlucon, D.B., Hedges, J.I., 1997. The effect of grain size and surface area on organic matter, lignin and carbohydrate concentration, and molecular compositions in Peru Margin sediments. Geochem. Cosmochim. Acta 61, 1247-1260.

Boyle, A.W., Silvin, C.J., Hassett, J.P., Nakas, J.P., Tanenbaum, S.W., 1992. Bacterial PCB biodegradation. Biodegradation 3, 285-298. https://doi.org/10.1007/ BF00129089.

BPS, 2016. Consumption Expenditure of Population of Indonesia by Province - Based on the March 2016 Susenas. Statistics Indonesia, Jakarta.

BPS, 2019. Statistical Yearbook of Indonesia 2019 BPS-Statistics Indonesia (Jakarta).

Burdige, D.J., 2007. Preservation of organic matter in marine Sediments: controls, mechanisms, and an imbalance in sediment organic carbon budgets? Chem. Rev. 107, 467-485. https://doi.org/10.1021/cr050347q.

CCME (Canadian Council of Minister of the Environment), 1999. Canadian quality guidelines for the protection of aquatic life: Summary table: Canadian environmental quality guideline, Winnipeg, Manitoba.

DLH, 2014. Tegal regency environmental agency strategic plan 2014-2019. In: Tegal, D.-E.A. o. (Ed.), DLH-environmental Agency of Tegal, Slawi, p. 39.

Doong, R.-A., Sun, Y.-C., Liao, P.-L., Peng, C.-K., Wu, S.-C., 2002. Distribution and fate of organochlorine pesticide residues in sediments from the selected rivers in Taiwan. Chemosphere 48, 237-246. https://doi.org/10.1016/S0045-6535(02) 00066-8.

Dsikowitzky, L., Nordhaus, I., Jennerjahn, T.C., Khrycheva, P., Sivatharshan, Y., Yuwono, E., Schwarzbauer, J., 2011. Anthropogenic organic contaminants in water, sediments and benthic organisms of the mangrove-fringed Segara Anakan Lagoon, Java, Indonesia. Mar. Pollut. Bull. 62, 851-862. https://doi.org/ 10.1016/j.marpolbul.2011.02.023.

Fao, Statistics C.W.P.o.F, 2004. Handbook of Fishery Statistical Standards Food and Agriculturan Organization. FAO), Rome.

FDA, 2020. Fish and fishery products hazards and controls guidance. In: Administration, F.a.D. (Ed.), U.S. Department of Health and Human Services. Food and Drug Administration, Florida, p. 437.

FDEP, 1994. Approach to the assessment of sediment quality in Florida coastal waters. In: Ofice of Water Policy. Florida Department of Environmental Protection (FDEP), Tallahassee, Florida. F. D. o. E. P. F.

Fitriyani, D., Turtiantoro, Sulistyowati, 2017. Analisis kebijakan pemerintah kabupaten tegal dalam mengatasi pencemaran limbah industri logam (studi kasus industri logam di Desa pesarean kecamatan adiwerna kabupaten tegal). Journal of Politic and Government Studies 6, 51-60.

Flemming, B.W., Delafontaine, M.T., 2000. Mass physical properties of muddy intertidal sediments: some applications, misapplications and non-applications. Continent. Shelf Res. 20, 1179-1197. https://doi.org/10.1016/S0278-4343(00) 00018-2.

Frignani, M., Piazza, R., Bellucci, L.G., Cu, N.H., Zangrando, R., Albertazzi, S., Moret, I., Romano, S., Gambaro, A., 2007. Polychlorinated biphenyls in sediments of the tam giang-cau Hai lagoon, central Vietnam. Chemosphere 67, 1786-1793. https://doi.org/10.1016/j.chemosphere.2006.05.119.

Galindo Reyes, J., Medina Jasso, A., Villagrana Lizarraga, C., 1996. Toxic effects of organochlorine pesticides on Penaeus vannamei. Shrimps in Sinaloa, Mexico. Chemosphere 33, 567-575. https://doi.org/10.1016/0045-6535(96)00183-X.

Gao, D., Chen, G., Li, X., Lin, X., Zeng, C., 2018. Reclamation culture alters sediment phosphorus speciation and ecological risk in coastal zone of southeastern China. Clean 46, 1700495. https://doi.org/10.1002/clen.201700495.

Gao, D., Liu, M., Hou, L., Derrick, Y.F.L., Wang, W., Li, X., Zeng, A., Zheng, Y., Han, P. Yang, Y., Yin, G., 2019. Effects of shrimp-aquaculture reclamation on sediment nitrate dissimilatory reduction processes in a coastal wetland of southeastern China. Environ. Pollut. 255, 113219. https://doi.org/10.1016/ j.envpol.2019.113219.

Gavrilescu, M., 2005. Fate of pesticides in the environment and its bioremediation. Eng. Life Sci. 5, 497-526. https://doi.org/10.1002/elsc.200520098.

Gioia, R., Lohmann, R., Dachs, J., Temme, C., Lakaschus, S., Schulz-Bull, D., Hand, I., Jones, K.C., 2008. Polychlorinated biphenyls in air and water of the north atlantic and arctic ocean. J. Geophys. Res.: Atmosphere 113. https://doi.org/ 10.1029/2007JD009750.

González-Mille, D.J., Ilizaliturri-Hernández, C.A., Espinosa-Reyes, G., CostillaSalazar, R., Díaz-Barriga, F., Ize-Lema, I., Mejía-Saavedra, J., 2010. Exposure to persistent organic pollutants (POPs) and DNA damage as an indicator of environmental stress in fish of different feeding habits of Coatzacoalcos, Veracruz, Mexico. Ecotoxicology 19, 1238-1248. https://doi.org/10.1007/s10646-0100508-X.

Guo, L., Qiu, Y., Zhang, G., Zheng, G.J., Lam, P.K.S., Li, X., 2008. Levels and bioaccumulation of organochlorine pesticides (OCPs) and polybrominated diphenyl ethers (PBDEs) in fishes from the Pearl River estuary and Daya Bay, South China. Environ. Pollut. 152, 604-611. https://doi.org/10.1016/ j.envpol.2007.06.067.

Hirano, T., Ishida, T., Oh, K., Sudo, R., 2007. Biodegradation of chlordane and hexachlorobenzenes in river sediment. Chemosphere 67, 428-434. https://doi.org/ 10.1016/j.chemosphere.2006.09.087.

Hu, Y., Sun, S., Song, X., Ma, J., Ru, S., 2015. Distribution and ecological risk assessment of HCHs and DDTs in surface seawater and sediment of the mariculture area of Jincheng Bay, China. J. Ocean Univ. China 14, 301-308. https:// doi.org/10.1007/s11802-015-2303-Z.

Huo, S., Li, C., Xi, B., Yu, Z., Yeager, K.M., Wu, F., 2017. Historical record of polychlorinated biphenyls (PCBs) and special occurrence of PCB 209 in a shallow fresh-water lake from eastern China. Chemosphere 184, 832-840. https:// doi.org/10.1016/j.chemosphere.2017.06.073.

IARC, WHO, 2016. Polychlorinated Biphenyls and Polybrominated Biphenyls International Agency for Research on Cancer (IARC). FR, Lyon.

Islam, R., Kumar, S., Karmoker, J., Kamruzzaman, M., Rahman, M.A., Biswas, N., Tran, T.K.A., Rahman, M.M., 2018. Bioaccumulation and adverse effects of persistent organic pollutants (POPs) on ecosystems and human exposure: a review study on Bangladesh perspectives. Environmental Technology \& Innovation 12, 115-131. https://doi.org/10.1016/j.eti.2018.08.002.

Jaikanlaya, C., Settachan, D., Denison, M.S., Ruchirawat, M., van den Berg, M., 2009. PCBs contamination in seafood species at the Eastern Coast of Thailand. Chemosphere 76, 239-249. https://doi.org/10.1016/j.chemosphere.2009.03.018.

Keil, R.G., Hedges, J.I., 1993. Sorption of organic matter to mineral surfaces and the preservation of organic matter in coastal marine sediments. Chem. Geol. 107, 385-388. https://doi.org/10.1016/0009-2541(93)90215-5.

Kurniasih, S., Setiani, O., Nugraheni, S., 2013. Factors related to pesticides exposure and anemia on horticultural farmers in gombong village belik sub district Pemalang central Java. Jurnal Kesehatan Lingkungan Indonesia 12. https:// doi.org/10.14710/jkli.12.2.132\%20-\%20137.

Lee, J., Kwon, B.-O., Kim, B., Noh, J., Hwang, K., Ryu, J., Park, J., Hong, S., Khim, J.S., 2019. Natural and anthropogenic signatures on sedimentary organic matters across varying intertidal habitats in the Korean waters. Environ. Int. 133, 105166. https://doi.org/10.1016/j.envint.2019.105166.

Li, Y.F., 1999. Global technical hexachlorocyclohexane usage and its contamination consequences in the environment: from 1948 to 1997. Sci. Total Environ. 232, 121-158. https://doi.org/10.1016/S0048-9697(99)00114-X.

Lin, S., Zhao, B., Ying, Z., Fan, S., Hu, Z., Xue, F., Zhang, Q., 2020. Residual characteristics and potential health risk assessment of polychlorinated biphenyls (PCBs) in seafood and surface sediments from Xiangshan Bay, China (20112016). Food Chem. 327, 126994. https://doi.org/10.1016/ j.foodchem.2020.126994.

Liu, W.-X., Wang, Y., He, W., Qin, N., Kong, X.-Z., He, Q.-S., Yang, B., Yang, C., Jiang, Y.J., Jorgensen, S.E., Xu, F.-L., 2016. Aquatic biota as potential biological indicators of the contamination, bioaccumulation and health risks caused by organochlorine pesticides in a large, shallow Chinese lake (Lake Chaohu). Ecol. Indicat. 60, 335-345. https://doi.org/10.1016/j.ecolind.2015.06.026.

Liu, X., Fiedler, H., Gong, W., Wang, B., Yu, G., 2018. Potential sources of unintentionally produced $\mathrm{PCB}, \mathrm{HCB}$, and PeCBz in China: a preliminary overview. Front. Environ. Sci. Eng. 12, 1. https://doi.org/10.1007/s11783-018-1036-9.

Long, E.R., MacDonald, D.D., 1998. Recommended uses of empirically derived, sediment quality guidelines for marine and estuarine ecosystems. Hum. Ecol. Risk Assess. 4, 1019-1039. https://doi.org/10.1080/10807039891284956.

Long, E.R., Macdonald, D.D., Smith, S.L., Calder, F.D., 1995. Incidence of adverse biological effects within ranges of chemical concentrations in marine and estuarine sediments. Environ. Manag. 19, 81-97. https://doi.org/10.1007/ BF02472006.

Lv, M., Luan, X., Guo, X., Liao, C., Guo, D., Miao, J., Wu, X., Zhou, R., Liu, D., Wang, D., Zhao, Y., Chen, L., 2020. A national-scale characterization of organochlorine pesticides (OCPs) in intertidal sediment of China: occurrence, fate and influential factors. Environ. Pollut. 257, 113634. https://doi.org/10.1016/ j.envpol.2019.113634.

Macdonald, D.D., Carr, R.S., Calder, F.D., Long, E.R., Ingersoll, C.G., 1996. Development 
and evaluation of sediment quality guidelines for Florida coastal waters. Ecotoxicology 5, 253-278. https://doi.org/10.1007/BF00118995.

Maldonado, C., Bayona, J.M., 2002. Organochlorine compounds in the northwestern black Sea water: distribution and water column process. Estuar. Coast Shelf Sci. 54, 527-540. https://doi.org/10.1006/ecss.2000.0672.

Martínez-Córdova, L.R., Peña-Messina, E., 2005. Biotic communities and feeding habits of Litopenaeus vannamei (Boone 1931) and Litopenaeus stylirostris (Stimpson 1974) in monoculture and polyculture semi-intensive ponds. Aquacult. Res. 36, 1075-1084. https://doi.org/10.1111/j.1365-2109.2005.01323.x.

McLeese, D.W., Metcalfe, C.D., Pezzack, D.S., 1980. Uptake of PCBs from sediment byNereis virens andCrangon septemspinosa. Arch. Environ. Contam. Toxicol. 9, 507-518. https://doi.org/10.1007/BF01056931.

BMI; GeoChem MetrixInc; US.Navy SPAWAR; USEPA, 2012. A Handbook for Determining the Sources of PCB Contamination in Sediments NAVFAC Engineering and Expeditionary. Warfare Center, Ohio.

Mitra, S., Corsolini, S., Pozo, K., Audy, O., Sarkar, S.K., Biswas, J.K., 2019. Characterization, source identification and risk associated with polyaromatic and chlorinated organic contaminants (PAHs, PCBs, PCBzs and OCPs) in the surface sediments of Hooghly estuary, India. Chemosphere 221, 154-165. https:// doi.org/10.1016/j.chemosphere 2018.12.173.

Mueller, J.F., Mortimer, M.R., O’Brien, J., Komarova, T., Carter, S., 2011. A cleaner river: long term use of semipermeable membrane devices demonstrate that concentrations of selected organochlorines and PAHs in the Brisbane River estuary, Queensland have reduced substantially over the past decade. Mar. Pollut. Bull. 63, 73-76. https://doi.org/10.1016/j.marpolbul.2011.03.026.

Neves, P.A., Colabuono, F.I., Ferreira, P.A.L., Kawakami, S.K., Taniguchi, S., Figueira, R.C.L., Mahiques, M.M., Montone, R.C., Bicego, M.C., 2018. Depositional history of polychlorinated biphenyls (PCBs), organochlorine pesticides (OCPs) and polycyclic aromatic hydrocarbons (PAHs) in an Amazon estuary during the last century. Sci. Total Environ. 615, 1262-1270. https://doi.org/10.1016/ j.scitotenv.2017.09.303.

NOAA, 2008. Screening quick references tables. In: Administration, N.N. O.a.A. (Ed.), Office of Response \& Restoration, National Oceanic and Atmospheric Administration.

Olisah, C., Okoh, O.O., Okoh, A.I., 2019. Distribution of organochlorine pesticides in fresh fish carcasses from selected estuaries in Eastern Cape Province, South Africa, and the associated health risk assessment. Mar. Pollut. Bull. 149 https:// doi.org/10.1016/j.marpolbul.2019.110605.

OSPAR, 2001. Polychlorinated Biphenyls (PCBs).

Plimmer, J.R., 1992. Dissipation of pesticides in the environment. In: Schnoor, J.L. (Ed.), Fate of Pesticides and Chemicals in the Environment. Wiley, New York.

Qiu, Y.-W., Qiu, H.-L., Zhang, G., Li, J., 2019. Bioaccumulation and cycling of organochlorine pesticides (OCPs) and polychlorinated biphenyls (PCBs) in three mangrove reserves of south China. Chemosphere 217, 195-203. https://doi.org/ 10.1016/j.chemosphere.2018.10.188.

Regency, Pemalang, 2019. Performance Information Documents of Regional Environmental Management (DIKPLHD) Pemalang District 2019, Pemalang Regency Gov (Pemalang).

Ross, P.S., Birnbaum, L.S., 2003. Integrated human and ecological risk assessment: a case study of persistent organic pollutants (POPs) in humans and wildlife. Hum. Ecol. Risk Assess. 9, 303-324. https://doi.org/10.1080/727073292.

Sather, P.J., Ikonomou, M.G., Haya, K., 2006. Occurrence of persistent organic pollutants in sediments collected near fish farm sites. Aquaculture 254, 234-247. https://doi.org/10.1016/j.aquaculture.2005.08.027.

Serrano, O., Lavery, P.S., Duarte, C.M., Kendrick, G.A., Calafat, A., York, P.H., Steven, A.D., Macreadie, P.I., 2016. Can mud (silt and clay) concentration be used to predict soil organic carbon content within seagrass ecosystems? Biogeosciences 17, 4915-4926. https://doi.org/10.5194/bg-13-4915-2016.

Song, C., Zhang, C., Zhang, J., Zhang, X., 2019. Occurrences and patterns of residual organochlorine pesticides (OCPs) in cultured Chinese mitten crab (Eriocheir sinensis) in China: concentrations, sources, and a human health risk assessment. Environ. Sci. Pollut. Control Ser. 26, 4952-4960. https://doi.org/10.1007/ s11356-018-3981-z.

Suhartono, Djokomoeljanto R.S., Hadisaputro, S., Subagio, H., Kartini, A., Suratman, 2012. Pesticide exposure as a risk factor for hypothyroidism in women at childbearing age in agricultural areas. Media Med. Indones. 46.

Susanto, A., Wulan, R., Puto, E., 2016. Used oil utilization for lime production as hazardous waste minimization. Int. J. Wine Res. 6 https://doi.org/10.4172/22525211.1000252

Tan, L., He, M., Men, B., Lin, C., 2009. Distribution and sources of organochlorine pesticides in water and sediments from daliao River Estuary of liaodong Bay, bohai Sea (China). Estuarine. Coastal and Shelf Science 84, 119-127. https:// doi.org/10.1016/j.ecss.2009.06.013.

Tang, D., Liu, X., He, H., Cui, Z., Gan, H., Xia, Z., 2020. Distribution, sources and ecological risks of organochlorine compounds (DDTs, HCHs and PCBs) in surface sediments from the Pearl River Estuary, China. Mar. Pollut. Bull. 152, 110942. https://doi.org/10.1016/j.marpolbul.2020.110942.

Tatem, H.E., 1986. Bioaccumulation of polychlorinated biphenyls and metals from contaminated sediment by freshwater prawns,Macrobrachium rosenbergii and clams,Corbicula fluminea. Arch. Environ. Contam. Toxicol. 15, 171-183. https:// doi.org/10.1007/BF01059966.

Tham, T.T., Anh, H.Q., Trinh, L.T., Lan, V.M., Truong, N.X., Yen, N.T.H., Anh, N.L., Tri, T.M., Minh, T.B., 2019. Distributions and seasonal variations of organochlorine pesticides, polychlorinated biphenyls, and polybrominated diphenyl ethers in surface sediment from coastal areas of central Vietnam. Mar. Pollut Bull. 144, 28-35. https://doi.org/10.1016/j.marpolbul.2019.05.009.

Totten, L.A., Gigliotti, C.L., VanRy, D.A., Offenberg, J.H., Nelson, E.D., Dachs, J. Reinfelder, J.R., Eisenreich, S.J., 2004. Atmospheric concentrations and deposition of polychorinated biphenyls to the hudson River estuary. Environ. Sci. Technol. 38, 2568-2573. https://doi.org/10.1021/es034878c.

Tran, T.A.M., Malarvannan, G., Hoang, T.L., Nguyen, V.H., Covaci, A., Elskens, M., 2019. Occurrence of organochlorine pesticides and polychlorinated biphenyls in sediment and fish in Cau Hai lagoon of Central Vietnam: human health risk assessment. Mar. Pollut. Bull. 141, 521-528. https://doi.org/10.1016/ j.marpolbul.2019.03.006.

USEPA, 2017. Polychlorinated Biphenyls (PCBs): Table of Aroclors. United States Environmental Protection Agency, Washington, D.C.

Van den Berg, M., Birnbaum, L.S., Denison, M., De Vito, M., Farland, W., Feeley, M. Fiedler, H., Hakansson, H., Hanberg, A., Haws, L., Rose, M., Safe, S., Schrenk, D. Tohyama, C., Tritscher, A., Tuomisto, J., Tysklind, M., Walker, N., Peterson, R.E. 2006. The 2005 World Health Organization reevaluation of human and Mammalian toxic equivalency factors for dioxins and dioxin-like compounds. Toxicol. Sci. : an official journal of the Society of Toxicology 93, 223-241. https://doi.org/10.1093/toxsci/kfl055.

Varadharajan, D., Pushparajan, N., 2013. Food and feeding habits of aquaculture candidate a potential crustacean of pacific white shrimp Litopenaeus vannamei, South East coast of India. J. Aquacult. Res. Dev. 4 https://doi.org/10.4172/21559546.1000161.

Voorspoels, S., Covaci, A., Maervoet, J., De Meester, I., Schepens, P., 2004. Levels and profiles of PCBs and OCPs in marine benthic species from the Belgian north Sea and the western scheldt estuary. Mar. Pollut. Bull. 49, 393-404. https://doi.org 10.1016/j.marpolbul.2004.02.024.

Walker, K., Vallero, D.A., Lewis, R.G., 1999. Factors influencing the distribution of lindane and other hexachlorocyclohexanes in the environment. Environ. Sci. Technol. 33, 4373-4378. https://doi.org/10.1021/es990647n.

Wang, H.-s., Du, J., Leung, H.-m., Oi Wah Leung, A., Liang, P., Giesy, J.P., Wong, C.K.C., Wong, M.-H., 2011. Distribution and source apportionments of polychlorinated biphenyls (PCBs) in mariculture sediments from the Pearl River Delta, South China. Mar. Pollut. Bull. 63, 516-522. https://doi.org/10.1016/ j.marpolbul.2011.02.009.

Wang, H.-S., Chen, Z.-J., Cheng, Z., Du, J., Man, Y.-B., Leung, H.-M., Giesy, J.P. Wong, C.K.C., Wong, M.-H., 2014. Aquaculture-derived enrichment of hexachlorocyclohexanes ( $\mathrm{HCHs}$ ) and dichlorodiphenyltrichloroethanes (DDTs) in coastal sediments of Hong Kong and adjacent mainland China. Sci. Total Environ. 466-467, 214-220. https://doi.org/10.1016/j.scitotenv.2013.07.027.

Wang, W., Bai, J., Zhang, G., Jia, J., Wang, X., Liu, X., Cui, B., 2019. Occurrence, sources and ecotoxicological risks of polychlorinated biphenyls (PCBs) in sediment cores from urban, rural and reclamation-affected rivers of the Pearl River Delta, China. Chemosphere 218, 359-367. https://doi.org/10.1016 j.chemosphere.2018.11.046.

Webster, L., Roose, P., Bersuder, B., Kotterman, M., Haarich, M., Vorkamp, K., 2013. Determination of Polychlorinated Biphenyls (PCBs) in Sediment and Biota. International Council for the Exploration of the Sea, Copenhagen, p. 18.

Wischkaemper, H.K., Beliveau, A.F., Henderson, R.W., 2013. USEPA Regional 4 Technical Services Issue Paper for Polychlorinated Biphenyl Characterization at Region 4 Superfund and RCRA Sites.

Yang, P., Bastviken, D., Lai, D.Y.F., Jin, B.S., Mou, X.J., Tong, C., Yao, Y.C., 2017. Effects of coastal marsh conversion to shrimp aquaculture ponds on $\mathrm{CH} 4$ and N2O emissions. Estuar. Coast Shelf Sci. 199, 125-131. https://doi.org/10.1016 j.ecss.2017.09.023

Yu, B.-W., Jin, G.-Z., Moon, Y.-H., Kim, M.-K., Kyoung, J.-D., Chang, Y.-S., 2006 Emission of PCDD/Fs and dioxin-like PCBs from metallurgy industries in S. Korea. Chemosphere 62, 494-501. https://doi.org/10.1016/ j.chemosphere.2005.04.031.

Zhang, G., Pan, Z., Bai, A., Li, J., Li, X., 2014. Distribution and bioaccumulation of organochlorine pesticides (OCPs) in food web of Nansi Lake, China. Environ Monit. Assess. 186, 2039-2051. https://doi.org/10.1007/s10661-013-3516-5.

Zhang, Y., Qi, S., Xing, X., Yang, D., Devi, N.L., Qu, C., Liu, H.-X., Zhang, J.-Q., Zeng, F.M., 2018. Legacies of Organochlorine Pesticides (OCPs) in Soil of China-A Review, and Cases in Southwest and Southeast China, Environmental Geochemistry: Site Characterization, Data Analysis and Case Histories, pp. 543-565.

Zhao, Z., Zhang, L., Wu, J., Fan, C., 2009. Distribution and bioaccumulation of organochlorine pesticides in surface sediments and benthic organisms from Taihu Lake, China. Chemosphere 77, 1191-1198. https://doi.org/10.1016/ j.chemosphere.2009.09.022

Zhao, Q., Bai, J., Lu, Q., Gao, Z., Jia, J., Cui, B., Liu, X., 2016. Polychlorinated biphenyls (PCBs) in sediments/soils of different wetlands along 100-year coastal reclamation chronosequence in the Pearl River Estuary, China. Environ. Pollut. 213, 860-869. https://doi.org/10.1016/j.envpol.2016.03.039.

Zhong, T., Niu, N., Li, X., Zhang, D., Zou, L., Yao, S., 2020. Distribution, composition profiles, source identification and potential risk assessment of Polychlorinated Biphenyls (PCBs) and Dechlorane Plus (DP) in sediments from Liaohe Estuary. Regional Studies in Marine Science 36. https://doi.org/10.1016 j.rsma.2020.101291.

Zhou, H., Chen, C.-M., Diao, X., 2020. Chapter 5 - the metabolic responses of aquatic animal exposed to POPs. In: Álvarez-Muñoz, D., Farré, M. (Eds.), Environmental Metabolomics. Elsevier, pp. 121-161. 